

$$
09
$$




\title{
THE BIOLOGICAL FOUNDATIONS OF BELIEF
}

By

WESLEY RAYMOND WELLS, PH.D. Assistant Professor of Philosophy, Colby College, Watcrville, Maine

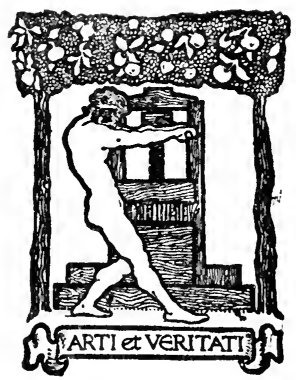

\author{
BOSTON \\ RICHARD G. BADGER \\ THE GORHAM PRESS
}


Copyright, 1921, by Richard G. Badger

All Rights Reserved

\section{$2101 \mathrm{~A}$}

MADE IN THE UNITED STATES OF AMERICA The Gorham PRess, Boston, U. S. A. 
TO THE MEMORY OF MY BROTHER ORION VASSAR WELLS, M. D. 



\section{PREFACE}

The past two decades have witnessed the rapid growth of an interest in the psychology of religion. Many books have been written in this field since the publication in I 902 of William James's Varieties of Religious Experience. The recent development of psychology into behaviorism suggests the importance of a behavioristic study of religion. Such a study should reflect the biological tendencies of behaviorism. It should deal with religious belief in terms of human behavior, having effects upon individual and racial survival. This book attempts to do just this-to study the biological foundations of belief.

Though the biological view-point is maintained throughout, the logical question of the truth or falsity of the religious beliefs that are valuable occasionally arises. James and other pragmatists have confused matters of logic and biology to the extent of claiming that the survival value of beliefs is a test of the truth of these beliefs. In order to avoid the suspicion of any such confusion in this book, I have pointed out what I have called the pragmatic fallacy, which is committed by such pragmatists as James and Dr. Schiller; and I have pointed out another fallacy frequently com- 
mitted by James and by numerous others, which I have called the fallacy of false attribution. I have tried to maintain the thesis that religious beliefs may be biologically valuable regardless of their truth, and that they may survive indefinitely just because of this most fundamental of all reasons, the biological reason. My position is stated at the outset, in the first chapter. Then Chapter II deals with religious fallacies. Chapters III and IV classify religious values, point out further biological grounds of belief, and take account of criticisms that have been made of my discussion of religious fallacies. Chapter $\mathrm{V}$ is a study of the value of religious beliefs as a means of moral training during childhood and youth. Chapter V contains also a discussion of the moral and religious value of philosophy for college undergraduates. These questions of religious and moral education are taken up in the light of a biologically grounded psychology.

The book consists entirely of articles that have been published during the past four years. Thanks are due to the editors of the Journal of Philosophy, Psychology, and Scientific Methods, and of the American Journal of Psychology for permission to reprint articles that first appeared in their columns. It is hoped that these articles may be found to have sufficient unity of plan and purpose 


$$
\text { Preface }
$$

to justify the present work of collection and arrangement. Such unity as may exist is the result, first of all, of the fact that all of the articles contained in the book are a direct outgrowth of my doctor's thesis written at Harvard University in r9I7, a thesis entitled $A$ Behavioristic Study of Religious Values.

Wesley Raymond Wells

Colby College, January, I 92 I 


\section{CONTENTS}

CHAPTER I

PAGE

The Biological Value of Religious Belief.... I

NOTE TO CHAPTER I

Religious Belief and the Population Question 2 I

CHAPTER II

The Pragmatic Fallacy and the Fallacy of False Attribution ........... 27

\section{CHAPTER III}

A Classification of Religious Values..... 42

\section{CHAPTER IV}

On Truth and Survival Value......... 68

CHAPTER V

Religious and Moral Education........ 93 

THE BIOLOGICAL FOUNDATIONS OF BELIEF 



\section{The Biological Foundations of Belief}

\section{CHAPTER I}

THE BIOLOGICAL VALUE OF RELIGIOUS BELIEF ${ }^{1}$

$\mathrm{S}^{\mathrm{O}}$ far as religious belief can be shown to be a

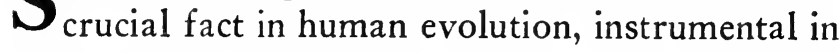
adapting the individual and the race to the environment, biological terms may properly be extended to include religion, or at least to include its instinctive and emotional sources. Whatever is essential to the successful ongoing of life processes possesses a truly biological significance. I propose to point out the vital importance of religious belief and its biological utility during the course of human evolution.

\section{I}

Whether God, freedom, and immortality are realities or not, of one thing there is no question: it is a fact, for any observer to take note of, that in many minds there exists the belief in these ob-

\footnotetext{
${ }^{1}$ This essay is reprinted from the American Journal of Psychology, Vol. XXIX (1918), pp. 383-92.
} 
jects. Religious beliefs are real as psychological facts regardless of the reality of the objects of the beliefs. It would be possible to construct a philosophy of religion wholly upon the fact and the value of religious belief, without raising the further question of the existence of the objects believed in, or even if we assumed the unreality of such objects. Beliefs may exist and have value for those who hold them as true even though they are entirely false, since the subjective effects of beliefs are independent of the question of truth; and it is even possible that religion is too good to be true.

Religion would continue in the world indefinitely upon the sheer basis of belief as a psychological fact, a biologically justified fact, even if the whole scientific and philosophical portion of mankind had agreed in branding all religious objects as unreal. James expresses the emotional necessity of religious beliefs for the majority of people when he says," "Materialism and agnosticism, even were they true, could never gain universal and popular acceptance; for they both, alike, give a solution of things which is irrational to the practical third of our nature, and in which we can never volitionally feel at home." Careful observers would have said, even before Professor Leuba's recent study ${ }^{3}$

\footnotetext{
${ }^{2} \mathrm{Wm}$. James, The Will to Believe, p. 126.

'J. H. Leuba, The Belief in God and Immortality, Boston, I9I6.
} 
of the actual religious beliefs of American scientists showed that it is so, that the majority of scientists do not believe in God or immortality. This fact is not so significant for the future of religion, however, as the fact that the majority of the parents of each new generation do have religious beliefs. The parents and homes, the churches and general social background, of each new generation, exert a greater influence upon the religious beliefs of people than do a few scientists who have ceased to require religious belief in order to maintain their vital equilibrium. Making the whole world scientific is impossible.

Beliefs exert a potent influence on life. The psychological and physiological effects of belief are shown strikingly in cases of primitive taboo where the belief that a taboo has been violated has, in numerous instances, caused death. Worldviews, beliefs about the ultimate things in man's total environment, are important influences on the physical economy of life. If two nations or races are equal in all respects except that the general philosophy and religion of the one is optimistic, and of the other, pessimistic, the race with the optimistic beliefs will survive in the struggle for existence, while the other race will be driven to the wall. As Goethe says:" "The real and sole

${ }^{4}$ Notes to Westöstlicher Divan, quoted in Paulsen's System of Ethics (Thilly's translation), p. 425. 
theme of the history of the world is the conflict between belief and unbelief. All epochs in which faith reigns supreme, under whatever form it may be, are bright, uplifting, and fruitful for contemporaries and posterity. All epochs, on the other hand, in which unbelief, in any form, gains a weak victory, even though temporarily boasting a sham glory, will pass away."

Several writers have given clear expression to the biological setting of religious belief. Professor Leuba says:" "The mere belief in gods may of itself produce results sufficient to make of religion a factor of the highest biological importance." "The biological point of view affords the more fruitful outlook. From this point of vantage religion appears as a part of the struggle for life." "Morality and religion . . ," says Professor Carver, "must be regarded as factors in the struggle for existence as truly as are weapons for offence and defence, teeth and claws, horns and hoofs, fur and feathers, plumage, beards, and antlers." "Who are the chosen people is not a historical question. It is a question of fact, adaptation, and survival. What is the true church will

'J. H. Leuba, A Psychological Study of Religion, pp. 14, 16-17.

'T. N. Carver, Essays in Social Justice, pp. 20, 31. 
The Biological Value of Religious Belief 5

never be determined by archaeological and historical investigation. It will be determined by the laws of selection and survival." Of the actual religious beliefs of the past, Read says," "Religion, in spite of its many drawbacks, has been so useful that families and tribes have been selected by their addiction to it."

The very fact of the existence of religious beliefs among all primitive peoples establishes a presumption in favor of the biological value of such beliefs. If at any time there have existed savage peoples without religious beliefs, they have not survived long in the struggle for life. All the peoples that have survived have possessed, among other things, religious beliefs. From this fact the evolutionist at once infers that religious beliefs must have been of some important service to the race. It might be argued against this by some objectors that the races which have survived have survived by virtue of other kinds of vital fitness, so that religious beliefs have counted neither for nor against survival. It is true that some organs exist the utility of which is not apparent. Since such variations have at least had no disutility, they have not been eliminated through the elimination of the organisms possessing them. But belief is of such practical importance that it can not by any

${ }^{7}$ Carveth Read, Natural and Social Morals, p. 226. 
possibility be regarded as neutral, that is, of no influence, favorable or unfavorable, in the struggle for existence. Consequently the universal existence of religious belief among primitive peoples is evidence of its survival value.

Some critics might admit that religious belief has been valuable in the past, during the infancy of the race, while they would argue that, like the vermiform appendix, it has outgrown its usefulness, or has even become a source of injury. G. E. Moore, for example, speaking of religious belief in modern society, says that "there is at least good room to doubt whether it ever does much good." 8 It can be shown, however, that religious belief still possesses value.

I would repeat that the question of truth is irrelevant to a discussion of the value of religious belief. I am studying the value of beliefs in their psychological context, without regard to the logical matter of truth. Actually, most of the early religious beliefs have had unreal objects, as all would agree, but their value is not thereby vitiated. Thus Read says," "As for the falsity of a whole religion in its peculiar doctrines, that (I fear we must admit) does not necessarily render it debas-

"'The Value of Religion," The International Journal of Ethics, Vol. XII (I901-02), p. 97.

${ }^{\circ} \mathrm{Op}$. cit., p. 229. 
ing or pernicious; for we have here an extreme case of that astonishing phenomenon in human life, the utility of illusion." And Rashdall says in like manner, "Error and delusion may be valuable elements in evolution; to a certain extent . . they have actually been so." ${ }^{10}$ Primitive religions have been the cause of many evils, it is true, but such evils have been more than counterbalanced by numerous positive values.

I said above that religious belief cannot be regarded as a neutral factor in the struggle for existence. The enormous effect of strong belief is well illustrated by instances of violated taboos among primitive peoples. Frazer cites many striking examples. ${ }^{11}$ A Maori slave, upon being told that the food which he had eaten had belonged to a chieftain, and was therefore taboo, "was seized by the most extraordinary convulsions and cramp in the stomach, which never ceased till he died about sundown the same day. . . A Maori woman having eaten of some fruit, and being afterwards told that the fruit had been taken from a tabooed place, exclaimed that the spirit of the chief, whose sanctity had been thus profaned, would kill her. This was in the afternoon, and

\footnotetext{
${ }^{10}$ Hastings Rashdall, The Theory of Good and Evil, Vol. II, p. 209.

${ }^{21}$ J. G. Frazer, The Golden Bough, 3rd edit., Part II, Taboo and the Perils of the Soul. See pp. 135-137.
} 
the next day by twelve o'clock she was dead." There is on record a case of a negro who ate a wild hen, which was taboo, upon the supposition that it was a domesticated fowl. Four years later he was told by his former host what he had eaten, whereupon he "immediately fell a-trembling, and suffered himself to be so far possessed with the effects of imagination, that he died in less than twenty-four hours." Many other instances of a similar sort are cited by Frazer. Such examples of the effects of belief in the case of violated taboos illustrate the general potency of belief. In the majority of cases, of course, taboos are not violated, on account of the beliefs about the consequences of violation, and so the race here receives its first moral instruction.

Though the hygienic value of optimistic religious beliefs in the case of the higher religions is important enough to make of religion a significant factor in the struggle for existence, religious beliefs have been of biological utility to a greater extent through their moral influence. In such forms of the higher religions as Christianity, both the moral and hygienic values are important. There are certain standards of conduct that are justified by the forces of natural selection, and it seems to be a fact that religious beliefs are the only sufficient instrumentality permanently to maintain 


\section{The Biological Value of Religious Belief}

these standards. McDougall says ${ }^{12}$ that the belief in immortality, which is one of the most central of religious beliefs, is essential to the survival of any nation because of its moralizing influence upon thought and conduct.

Some writers have attributed the beginnings and even the continued maintenance of all morality to religious belief. Thus Pfleiderer says, ${ }^{13}$ "The historical beginning of all morality is to be found in religion." And Caird says, ${ }^{14}$ "Religion and morality are necessary correlates of each other." Such extreme views are untenable, for certainly in modern society religion is not an essential condition of morality with all men; and in primitive society many kinds of right conduct have an instinctive basis, especially in the family relationships. Nevertheless, religious belief has enhanced primitive morality, and continues, on the whole, to possess positive moral value.

Primitive morality is fundamentally a matter of the customs, or mores, of the group. Morality is always and everywhere a social phenomenon, arising from the interaction of individuals in groups. A group of Hobbesian individuals is biologically inconceivable. Man, like most mem-

${ }^{12} \mathrm{Wm}$. McDougall, Body and Mind, Preface, pp. xiii, xiv. ${ }^{13}$ Otto Pfleiderer, Philosophy of Religion (Stewart and Menzies, translators), Vol. IV, p. 230.

${ }^{14}$ Edward Caird, The Evolution of Religion, Vol. I, p. 237. 
bers of the animal kingdom, possesses various social instincts. Group selection ${ }^{15}$ has tended to eliminate all of the too self-centered individuals. Since a group is stronger than an individual in the struggle for existence, only groups have survived; and, furthermore, the existence of groups requires the presence of social instincts in the individuals that make up the groups. Altruism is just as instinctive as egoism, and is probably derived chiefly from the parental instinct. In many of the lower animals the social instincts manifest themselves in various forms of gregariousness and mutual helpfulness, and much more is this the case with man. Thus primitive man is fitted for a moral life within groups by his aboriginal inheritance.

Acts are judged right or wrong by primitive man according as they conform or not to the group customs. So far as primitive customs are instinctive in origin, they have survival value, on the whole, since the instincts are one of the products of the struggle for existence. Religious beliefs enter, however, and complicate the situation. Many of the customs have a religious origin, and others are enforced by religious beliefs, especially by beliefs in taboo. Taboo is the original categorical

${ }^{16}$ See P. Kropotkin, Mutual Aid, a Factor of Evolution; Edward Westermarck, The Origin and Development of the Moral Ideas, Vol. II, Ch. XXXIV; Wm. James, Principles of Psychology, Vol. I, p. 325. 
imperative. It corresponds, in upholding early customs, to the "thou shall not" of the Mosaic code. Taboo is chiefly religious in origin, being based upon the belief in awful and mysterious penalties that will inevitably follow the infringment of certain rules. Since primitive morality consists of primitive custcms, or mores, taboo is instrumental to primitive morality through enforcing the mores. There are other means, such as public approval and disapproval, and physical force, of enforcing primitive customs, but belief in taboos is one of the very strongest guardians of primitive group morality. Primitive customs have possessed some disvalue, through hindering progress, but they have had positive survival value on the whole; and taboo, in enforcing customs, has possessed value in the struggle for existence. Furthermore, the primitive mores have contained the germs of much of our present morality; and taboo has, therefore, been instrumental to the maintenance of conduct that is right, as judged by modern standards.

There have been other values of early religious belief. Religious belief has had what may be called industrial value so far as the industrial arts have developed in connection with the worship of the gods. Religious belief has had scientific and philosophic value wherever pure science and phi- 
losophy have developed from religion. Belief in spirits, hero-ancestors, and gods, by increasing the extent and complexity of primitive man's environment, has stimulated intellectual activity. The worship of heavenly bodies has at least attracted serious attention to them, and consequently the science of astronomy owes something to early religious interests. Mythological accounts of the origin and nature of the world have stimulated curiosity about scientific questions, and have given place to more scientific cosmogonies and cosmologies. The various professions have had a religious origin. Priests and chieftains are often identical among primitive peoples. The medical profession has evolved from the work of medicine men. The first teachers were the priests and headmen, who gave instruction to the youth in the initiation ceremonies. There has been a close historical connection between theology and philosophy; and the early religious interest, first becoming intellectualized in the form of theology, has always tended to go over into general philosophy.

Among other values of early religious belief are artistic, social, and legal or political values. Primitive religious beliefs have had artistic value so far as poetry, music, sculpture, and architecture have developed out of the worship of the gods. Dancing and music were originally of religious signifi- 


\section{The Biological Value of Religious Belief I3}

cance. The drama traces its origin to religious ceremonials. The first poetry consisted of stories of the gods. The first architecture worthy of the name arose in the construction of altars and temples. In the creation of images of the gods, sculpture appeared. Early painting represented the deeds of the gods and of ancestoral heroes who had been deified. Social value has attached to early religious beliefs wherever the beliefs have been a bond uniting groups in the worship of common deities, supplementing the instinctive basis of group unity. Legal and political values of early religious beliefs appear in the development of property rights and stable forms of government. Taboo has played an important part in the development of rights of property. Holy places are at first the property of the gods. In the case of taboo on chiefs, it is sometimes the case that everything that a chief touches becomes his property. It is of importance for social evolution that the conception of property rights should have arisen early. More obvious is the connection between religion and government or law. The legal profession was originally undifferentiated from the priesthood, and the first laws of the state were religious laws.

Not only the moral value of early religious beliefs, but also the other values, which I have called 
industrial, scientific, artistic, social, and legal, have been genuine values of a biological sort.

\section{II}

The biological value of religious belief on the level of the higher religions, including Christianity, may not at first seem so obvious as in the case of the primitive religions. It is, however, even more important, inasmuch as our present-day interests are vitally affected in such practical ways by religious belief.

The most fundamental distinction between the lower, nature religions, and the higher, redemptive religions may be expressed in terms of the difference between desires for satisfactions of a temporal and physical sort, and desires for transcendent satisfactions. In the nature religions man is satisfied if he has worldly prosperity; and he believes in and desires transcendent realities only as instruments to the attainment of his worldly desires. It was not until a considerable degree of civilization had been reached that the redemptive religions could appear and maintain themselves. Natural selection, perhaps, accounts for the suppression of interests of a redemptive sort in the periods of prehistoric savagery and of primitive culture, through eliminating any idealistic individuals that may have appeared. A Wordsworthian 


\section{The Biological Value of Religious Belief I 5}

is not the kind of nature worshipper that would be fit to survive among primeval savages; but, in a social order of more refinement, idealistic beliefs possess a positive biological value for many individuals.

In the higher developments of the religious consciousness the hygienic value of religious belief, which now becomes instrumental to optimism and hence to health and survival, is perhaps a more important value than the moral value, though the latter is still significant. The complete denial of the existence of the objects of religious beliefs would reduce a large portion of mankind logically to the acceptance of Mr. Russell's statement, ${ }^{16}$ "Only on the firm foundation of unyielding despair, can the soul's habitation henceforth be safely built." This would be the logic of the situation, but not the biology of it. Despair means death, literally. A race that despaired would perish from the earth; but a hopeful faith means life, and gives life abundantly. Faith is biologically necessary for the human race, and it is a psychological fact that "hope springs eternal in the human breast." Mr. Russell's statement is contradicted by the facts of biology and psychology, for on a foundation of despair no habitation at all for the soul can possibly be built.

${ }^{10}$ Bertrand Russell, Philosophical Essays, p. 6I. 
Such a pessimism as Mr. Russell's is due as much to the pessimist's high ideals as to his beliefs about the objective nature of reality. Pessimism results from the belief in a fundamental misfit between reality and the objects of desire. The man who is content to be a brute, with a brute's desires, is not pessimistic if he finds the world fundamentally brutal. But to the man aware of the "noon-day brightness of human genius," pessimism comes if he believes that "the lofty thoughts that ennoble his little day" are insufficiently grounded in the ultimate nature of things.

For large numbers of individuals in modern society, belief in the reality of another world of which the physical world is but a shadow and a promise, is essential to optimism and to a healthy state of mind in general. Professor Hocking's assertion ${ }^{17}$ that optimism requires the denial of the reality of the world as it appears to be, together with belief in transcendent realities, is justified by the psychological facts so far as many persons (though not all) are concerned. The "Weltschmerz bred of reflection," or religious pessimism, according to James, "consists in nothing but a religious demand to which there comes no normal religious reply."18 "Its great reflective source has

\footnotetext{
${ }^{11}$ W. E. Hocking, The Meaning of God in Human Experience, p. 168.

${ }^{15}$ Wm. James, op. cit., p. 39.
} 
at all times been a contradiction between the phenomena of nature and the craving of the heart to believe that behind nature there is a spirit whose expression nature is." 19 "No brute can have this sort of melancholy; no man who is irreligious can become its prey. It is the sick shudder of the frustrated religious demand." ${ }^{20}$

The inevitable pessimism of naturalism for all persons of sensitive natures who are also reflective. and who take a wide view of reality, has been a frequent theme in prose and in poetry. Some lines in James Thomson's "City of Dreadful Night" express vividly the despair of religious pessimism:

" The man speaks sooth, alas! the man speaks sooth; We have no personal life beyond the grave; There is no God; Fate knows nor wrath nor ruth:

Can I find here the comfort which I crave?

"'Speak not of comfort where no comfort is, Speak not at all: can words make foul things fair? Our life's a cheat, our death a black abyss:

Hush, and be mute, envisaging despair.'

James points out two possible ways of relieving such pessimism. "The longing to read the facts religiously may cease, and leave the bare facts by themselves; or supplementary facts may be discovered or believed in, which permit the religious reading to go on." ${ }_{21}$ The first alternative would

\footnotetext{
${ }^{10}$ Ibid., p. 40.

${ }^{20}$ Ibid., p. 42.

${ }^{21} I$ Ibid., p. 4I.
} 
mean the giving up of religion and the acceptance of a materialistic philosophy. It is true that such a solution is accepted by many persons, but James emphasizes correctly the biological impossibility of the general acceptance of materialistic views by all of mankind. ${ }^{22}$ A spiritual view, on the other hand, releases hope and moral courage; and hope and moral courage are among the things men live by. Such religions as Christianity and Buddhism are essentially religions of deliverance from the vanity of worldly desires. Buddhism is pessimistic so far as the physical world is concerned, but its adherents are made optimistic, and so are enabled to survive in the physical world, through their beliefs in transcendent realties.

Browning's optimism was based upon religious idealism. Reality, as he believed it to be, coincided with what he valued most. Abt Vogler's keys gave their sounds to the wish of the musician's soul. In music this "wish flowed visibly forth." The man with an idealistic temperament will be an optimist only if he believes that this "palace of music," the objectification of lofty aspiration, is "founded flat on the nether springs" of realty. The religious idealist experiences all the emotions of spiritual sovereignty, believing, with the creative musical genius of Browning's poem,

${ }^{22} I b i d .$, Ch. IV. 
that "'tis we musicians know." By him, realty is taken to be such as to satisfy all his deepest longings. He believes that:

"All we have willed or hoped or dreamed of good shall exist; Not its semblance, but itself; no beauty, nor good, nor power

Whose voice has gone forth, but each survives for the melodist

When eternity affirms the conception of an hour."

Though man's emotional nature in so many cases requires idealistic and religious beliefs, it by no means follows that such beliefs are true. To maintain that the value of idealism implies its truth would be to commit the pragmatic fallacy. ${ }^{23}$ But there is every reason to think that large numbers will continue to accept religious idealism as true, simply because in so many cases man's emotions determine his beliefs. Those who predict the "irreligion of the future" fail to take into account the emotional and temperamental basis of belief. We may correctly conceive of the conflict between religion and irreligion, idealism and materialism, as a biological struggle between the "tender-minded" and the "tough-minded"; and the biological advantage lies to some extent with the "tender-minded" so far as their emotional cravings are satisfied by religious beliefs. Reliious beliefs not only make for optimism, but are

${ }^{23}$ See below, Ch. II. 
20 The Biological Foundations of Belief

also instrumental in motivating moral endeavor; and, consequently, in the highest as well as in the lowest forms of religion, religious beliefs have important biological values. 


\title{
NOTE TO CHAPTER I
}

\author{
RELIGIOUS BELIEF AND THE POPULATION \\ QUESTION $^{1}$
}

¿UCH considerations as have been presented in SChapter I ought to be supplemented by an account of one further situation, a very specific and concrete situation, in which religious belief manifests its biological value most strikingly. I refer to the correlation between religious belief and a relatively high birth-rate, especially in the case of belief of a somewhat legalistic sort such as is now best exemplified in Catholicism. This correlation is very significant. It shows that religious belief possesses survival value of a high order.

The connection between religious belief and the birth-rate in ancient history is a well-known fact. Fustel de Coulanges ${ }^{2}$ has pointed out how, in the patriarchal families of the ancient Greeks and Romans, religion required the continuity of the family. The fate of the ancestral spirits was believed to depend upon offerings made at their

\footnotetext{
${ }^{1}$ Reprinted from the American Journal of Psychology, Vol. XXXI (I920), pp. 204-207.

${ }^{2}$ The Ancient City, (translation by Willard Small), Boston, IIth edition, Igor.
} 
tombs by their descendants. Continuity of the family was required for the sake of the sustenance of the departed ancestors. Celibacy was an impiety, forbidden by religion and also by civil law when law arose out of religious requirements as something distinct from them. The ancient laws of Rome forbade celibacy. ${ }^{3}$ The ancient Hindus had similar laws. For the Hindus as for the Greeks and Romans the extinction of a family caused the ruin of the family religion, and this was to be avoided by all means. ${ }^{4}$ Among the ancient Hebrews also it was a fundamental religious duty to "be fruitful and multiply."

All this, however, is a matter of ancient history. It is more important to inquire about the relation between religious belief and increase of population in modern society.

In the first place, it seems a matter of common observation that, in general, the birth-rate is highest in families most influenced by religious belief. The reasons that might be assigned as the cause of this are various. In some cases the religiously inclined may feel a mystic obligation to rear a family. Fear of a concrete hell for those failing to fulfill their parental obligations may be the motivating power in other cases. Mr. Russell seems

'See Cicero, De Legibus, B'k III.

${ }^{4}$ See Fustel de Coulanges, op. cit., p. 62. 


\section{Religious Belief and Population Question 23}

to incline to this explanation, and to think that the belief in hell-fire is thus biologically justified, when he says, "Men and women who can still believe the Catholic faith will have a biological advantage; gradually a race will grow up which will be impervious to all the assaults of reason, and will believe imperturbably that limitation of families leads to hell-fire." ${ }_{5}$ A third possible explanation of the connection between a high birth-rate and religious belief is the partial identity of the parental instinct and the religious sentiment. According to McDougall, ${ }^{6}$ the tender emotion, which is a correlate of the parental instinct, is a constituent also of the religious sentiment.

In the second place, statistical studies have supported the conclusions of casual observation by showing it to be a fact that, where religious belief thrives, there a relatively high birth-rate is generally to be found. The Italian economist Nitti ${ }^{7}$ has called attention to this fact. M. Leroy-Beaulieu has made a statistical study of the situation, not only in France, but in various other countries as well. He has found a high birth-rate among the Spanish and Italian Catholics, and in those sections of France where the Catholic church is

"Bertrand Russell, "Marriage and the Population Question," International Journal of Ethics, Vol. XXVI (I9I5-I6), p. 45I. XIII.

'See Wm. McDougall, Social Psychology, pp. 66ff and Ch.

${ }^{\top}$ Franceseo S. Nitti, Population and the Social Order (translation), pp. I18-24. 
strong. ${ }^{8}$ McDougall ${ }^{9}$ accepts the contention of Benjamin $\mathrm{Kidd}^{10}$ that one great influence of religious belief has been, and continues to be, its instrumentality as a support of the parental instinct against the tendency towards prudential limitation of the birth-rate. Sidney $\mathrm{Webb}^{11}$ explains the high birth-rate among Catholics in England by reference to the fact that the Catholic church absolutely forbids any regulation of the marriage state. Of the distribution of the birth-rate he says, "It is significant that Ireland is the only part of the United Kingdom in which the birth-rate has not declined; that in Ireland itself it has declined a little in semi-Protestant Belfast, and not at all in Roman Catholic Dublin; and that in the towns of Great Britain the decline is least in Liverpool, Salford, Manchester, and Glasgow-towns in which the proportion of Roman Catholics is considerable." Webb finds that among the metro-

${ }^{8}$ Paul Leroy-Beaulieu, La Question de la Population. See especially pp. 395-402. Leroy-Beaulieu gives the following explanation of the influence of religion, especially Catholicism, on population: "La religion catholique, plus encore que toutes les autres, enseigne la résignation à son sort, condamne l'égö̈sme et déconseille l'ambition: c'est-à-dire, q'elle exalt. le sentiment qui tend à rendre les familles nombreuses ct qu'elle reprouve ceux qui tendent d diminuer le nombre des enfants." (Pp. 397, 98).

${ }^{\circ}$ p. cit., p. 272.

${ }^{10}$ See Benjamin Kidd, Social Evolution, p. 295 ; also Ch. V. See also Mr. and Mrs. Whetham, The Family and the Nation. ${ }^{11}$ The Decline of the Birth-Rate, Fabian Tract, No. I31, 1907. 12Ibid., p. 9. 
politan boroughs the highest birth-rate is "in those boroughs in which the Irish Roman Catholics (and the Jews who, in this respect, are in the same position) are most numerous." ${ }^{13}$ Many economists have tried to correlate high and low birth-rates with conditions of poverty and wealth, but Webb shows that there is a closer correlation with religious belief than with economic conditions. As a matter of fact, however, poverty and religious belief frequently exist together since many people find compensation in religion for the lack of the material satisfactions of life.

For a most complete and convincing array of statistics upon this subject, Mr. Meyrick Booth's article, "Religious Belief as Affecting the Growth of Population," ${ }^{14}$ should be consulted. Booth shows, for example, that, according to the Catholic Year Book for I9I4, the birth-rate per I,000. of Roman Catholics in Great Britain was 38.6, while the average rate for the whole population was but 24. In the United States, among those states which, according to the religious census of I 906, had a small population of Catholics, the birth-rate was low, averaging I 5 or less per I,ooo. On the other hand, in five states with a

${ }^{13}$ Ibid., p. 9.

${ }^{14}$ In the Hibbert Journal, Vol. XIII (1914-I5), pp. 138-54. 
large proportion of Catholics, the birth-rate averaged about 23 or 24 per I, Ooo. ${ }^{15}$

There may be a temperamental basis for susceptibility to religious belief, and temperament is hereditary. As McDougall says, ${ }^{16}$ basing his conclusions on the studies made by Karl Pearson, ${ }^{17}$ about one-half of each generation is recruited from one-quarter of the preceding generation. The quarter with the highest birth-rate is, as I have shown, the most religious portion of society. So far, then, as there is a temperamental basis for religious belief, and so far as temperament is hereditary, the religious temperament, and consequently religious belief, can not die out while the birth-rate is highest among those possessing the requisite temperament.

The correlation between religious belief and a relatively high birth-rate is most conclusive evidence of the biological value of religious belief. If unbelievers are not so much interested as others in founding families, then their unbelief perishes with them; while religious belief springs up in each new generation from a perennial source of vital human need.

\footnotetext{
${ }^{25}$ Booth's article is a careful study of the situation, and gives many tables of statistics, which should be consulted by any one who is not convinced of the importance of religious belief as influencing population increase. All the statistics used by Booth are uninfluenced by the World War, since they are for years not later than rigr.

${ }^{10} \mathrm{Op}$. cit., p. 273.

${ }^{17}$ See Carl Pearson, Chances of Death.
} 


\section{CHAPTER II}

THE PRAGMATIC FALLACY AND THE FALLACY OF

FALSE ATTRIBUTION ${ }^{1}$

7 HERE are two fallacies which are met with 1 so frequently in the literature of the philosophy of religion that they deserve explicit mention. The first, arising from a confusion between the value and the truth of religious beliefs, is so characteristic of the pragmatic way of thinking in the field of religion that it may properly be labeled the pragmatic fallacy. The second fallacy arises from the attribution of the so-called religious experience to outside, "higher" forces in cases where, in reality, the cause of the experience is merely physiological-from "below" and not from "above." This may be called the fallacy of false attribution.

${ }^{1}$ Reprinted, with change of title, from the Journal of Philosophy, Psychology, and Scientific Methods, Vol. XIV (1917), pp. 653-660. Since I published this article, in I917, Professor Leuba (Psychological Bulletin, Vol. XVI, p. 66, note) has called my attention to the fact that he pointed out the fallacy of false attribution, without naming it, in his discussion of James's mysticism in 1904 (International Journal of Ethics, Vol. XIV, pp. 323-29). He says, nevertheless, that my paper "may claim the merit of providing names for long recognized fallacies" (Loc. cit., p. 63). 
When value and truth are distinguished, and when it is seen that in many cases beliefs that are clearly false still have obvious value for those who hold them as true, then the argument so commonly used that, since certain religious beliefs possess value for the believers, they are therefore true, is seen to be unsound. Truth is definable in terms of correspondence with facts. Pragmatists accept this when they say, as James does, that beliefs "work," and are true, only if they agree winh reality; and they take the "working" of a belief as evidence that the belief does agree with reality. Truth is something that belongs to the subjectmatter of logic, while value has a field of its own. Value is the subject-matter of the special science of value, and there is a growing agreement in defining value in terms of organic interests. Things are made valuable when they are liked or desired, when satisfaction is derived from their presence or possession. The statement will, upon reflection, be challenged by few that there is nothing either good or bad, but liking or disliking makes it so. Those who do disagree with such a definition, calling value indefinable, as Mr. Russell and Mr. Moore do, ${ }^{2}$ or defining it in terms of har-

\footnotetext{
${ }^{2}$ Bertrand Russell, Philosophical Essays, pp. 4-15; G. E. Moore, Principia Ethica, pp. 5-I4.
} 
mony or fitness, ${ }^{3}$ etc., will still avoid any confusion between value and truth. Beliefs may be true or false; they may also have value or disvalue. In most cases, probably, true beliefs are valuable, and false beliefs have disvalue, but not in all cases. It is a fact that false religious beliefs have possessed value in the course of history; and it is undoubtedly true that false religious beliefs still possess value under some conditions.

Pragmatism is biological in its treatment of mind. Metal processes, according to pragmatism, have arisen as aids to the adjustment of organisms to their environment. In such a view as James's, truth and the survival value that beliefs possess in the biological struggle for existence are made synonymous, and it is just this that constitutes the pragmatic fallacy. It might be argued that, according to the instrumental theory of consciousness, no false beliefs, but only true beliefs, i. e., beliefs that correspond with reality, can be of biological utility ${ }^{4}$ through their instrumentality to the adjustment of the organism to its environment; but it is necessary to distinguish here, by reference to the objects of the two classes of beliefs, be-

${ }^{3}$ See G. H. Palmer, The Nature of Goodness.

"Biological utility or insirumentality is a case of value, for what is instrumental to life is indirectly the object of interest or desire, since life is valued with approximate universality. 
tween what I shall call "scientific" beliefs and "metaphysical" beliefs. "Scientific" beliefs a re beliefs about details of the physical environment. "Metaphysical" beliefs are beliefs about the nature of the universe as a whole, as $e . g$., the belief that the surface appearance of things is real, or the contrasting belief that ultimate reality is found only beneath the surface of appearances. The phenomenal universe is not a "whole," so if there is a fundamental unity about the universe, it can be found only in some transcendent aspect of it. Beliefs in transexperiential realities of any sort, also, whether or not there be a unity about the objects, would be called "metaphysical" beliefs. Many religious beliefs are of this sort. "Scientific" hypotheses, if they are of any significance, are capable of empirical verification with at least some degree of success; while "metaphysical" beliefs, as I have defined them, are incapable of empirical verification. The beliefs that must be true in order to be valuable in the long run, biologically and otherwise, are the ones that I call "scientific" beliefs. For example, the belief that the ice on the river is safe is a "scientific" belief. It can be verified by venturing upon the ice. Such a belief as this possesses biological value only if true, for to believe that the ice is safe when in reality it is not safe may be an indirect cause of death, in case I go skating 
and am drowned as a consequence. Beliefs of this "scientific" sort have disvalue unless they correspond with outside facts.

The case of "metaphysical" beliefs, however, is different. "Metaphysical" beliefs can not be verified by the practical process of discovering the sense-data that constitute the objects with which the propositions correspond, for they refer to no empirical objects. But if they refer to no empirical objects that can serve as their verification, neither can they lead to objective results that are harmful. Holding a false "metaphysical" belief can never have such bad objective consequences as holding a false "scientific" belief, e. g., a false belief about the condition of the ice; and the false "metaphysical" belief may, on the other hand, possess positive values of a subjective sort. "Scientific" beliefs, also, whether true or false, may have subjective effects of value; but, in the case of false "scientific" beliefs, the sum total of subjective and objective effects will have negative value in the long run. An error believed has the same subjective effect upon the believer as a truth believed. Even if we assumed naturalism to be the true metaphysical theory, it is plain that the (false) "tender-minded" belief in God would possess hygienic value for those who were made optimistic by the belief; and it would possess moral value for 
those who would not be moral without belief in supernatural sanctions. In the case of "metaphysical" beliefs, the effect is of a subjective sort, and is independent of the objective truth of the beliefs. A man in a naturalistic universe might profit from true "scientific" beliefs about the parts of the universe, and also from the emotional and moral effect of a false religious belief about the nature of the universe as a whole, its meaning, purpose, and the like. Many of the false religious beliefs of primitive man have had negative values so far as they have actually caused maladjustment to the physical environment by virtue of having "scientific" beliefs associated with them, but they have possessed numerous positive values, through being the source of moral instruction, of artistic production, of conceptions of law, etc. Much confusion will be avoided by keeping clear the distinction between the direct, subjective effects of "metaphysical" beliefs, and the indirect, objective effects of "scientific" beliefs. To believe in God, even if there be no God, can have no bad indirect, objective effect. On the other hand, the direct, subjective effects of religious beliefs upon conduct, happiness, etc., may be of such positive value as to be a determining factor in the biological struggle for existence. 


\section{Pragmatic Fallacy and False Attribution 33}

In The Will to Believe 5 James emphasizes the emotional and moral necessity of some sort of theistic belief for the majority of people. No other sort of world-view, he says, is congruent with human nature. He recognizes in this early work, too, that mere congruity with man's emotional nature is not the meaning or the test of truth. He says: "Theism, whatever its objective warrant, would thus be seen to have a subjective anchorage in its congruity with our nature as thinkers; and, however it may fare with its truth, to derive from this subjective adequacy the strongest possible guaranty of its permanency.... God may be called the normal object of the mind's belief. Whether over and above this $\mathrm{He}$ be really the living truth is another question. If $\mathrm{He}$ is, it will show the structure of the mind to be in accordance with the nature of reality." Though James here avoids the pragmatic fallacy by distinguishing the value of belief from its truth, his later developments of pragmatism obliterate the distinction, or they at least make emotional congruity sufficient evidence of truth in cases where verification by perception and consistency is impossible or inconclusive. It is this that Professor Perry refers to as the pragmatic method of "ver-

\footnotetext{
${ }^{5}$ Especially in Ch. IV.

${ }^{\circ} O p$ cit., p. II6. Italics mine.
} 
ification by sentiment," ${ }_{7}$ when verification proper is impossible. Since truth is a matter of logic and epistemology, the extra-logical matter of sentiment should not be admitted as a test of truth. Let us content ourselves by saying that unverifiable religious beliefs possess value or disvalue, and stop at this point, rather than confuse matters of psychology and theory of value with logic.

That James did not keep clear in his later writings on pragmatism the distinction between the value and the truth of belief is obvious, not only from the general spirit of pragmatism, but also from certain definite statements that he makes. $^{8}$

The pragmatic fallacy extends to the case of mysticism when employed as James employs it as evidence for the truth of religious belief. James concludes" that "personal religious experience has its root and centre in mystical states of consciousness." Furthermore, it is largely, if not wholly, because of the value possessed by mystical states for the mystics themselves that James accepts mysticism as evidence of the truth of religion. A few quotations from James will make clear his position. He says:10 "Mystical states indeed wield

'Present Philosophical Tendencies, pp. 209, 10.

${ }^{8}$ See Pragmatism, pp. 77, 204, 222, 273.

${ }^{\circ}$ Varieties of Religious Experience, p. 379.

${ }^{10} \mathrm{Ibid}$., pp. 428, 4I3 (italics mine), 400, $40 \mathrm{I}$. 


\section{Pragmatic Fallacy and False Attribution 35}

no authority due simply to their being mystical states." "To pass a spiritual judgment upon these states, we must ... inquire into their fruits for life." "The Vedantists says that one may stumble into superconsciousness sporadically, without the previous training, but then it is impure. Their test of its purity, like our test of religious value [= truth, as I have pointed out, for the pragmatist], is empirical: its fruits must be good for life. When a man comes out of Samâdhi, they assure us that he remains 'enlightened, a sage, a prophet, a saint, his whole character changed, his life changed, illumined.' " If mystical states have "no authority due to their being mystical states," and if it is only because of their value that they are accepted as evidence for the truth of the religious beliefs associated with them, or in terms of which they are interpreted by the mystics themselves, then here is another clear case of the pragmatic fallacy.

\section{II}

The question of the interpretation of mysticism leads up to the fallacy that I have called the fallacy of false attribution, which consists in the erroneous interpretation of an experience whereby the experience is attributed to an external, divine source in cases where a physiological explanation is adequate 
to account for the experience. Thus James says that the "inner" experiences, mystical in nature, which are central in religion, point to the intervention of superhuman powers. But it is possible that mysticism is only a form of emotionalism, explainable within a purely naturalistic scheme. Postponing for the moment a more thorough examination of mysticism, I will simply say that if mysticism is only a form of emotionalism, then the mystic, though indubitably passing through the experience, errs in ascribing to it a divine significance that does not belong to it. This is the fallacy of false attribution.

As Professor Hocking says, "To distinguish between what is subjective and what is objective about our experience is frequently difficult, even in physical observation; but especially in the experience of the mystic."11 The difficulty of distinguishing subjective from objective aspects of any experience that occurs when one is in an unusual physiological condition is well illustrated in Kipling's "La Nuit Blanche." Here a man with the "jims" on has remarkable experiences. He says:

"In the full, fresh, fragrant morning,

I observed a camel crawl,

Laws of gravitation scorning, On the ceiling and the wall."

This is only one of his spectacular experiences.

${ }^{11}$ The meaning of God in Human Experience, pp. 352, 353. 


\section{Pragmatic Fallacy and False Attribution 37}

He himself pertinently raises the question of the real objectivity of events in which the natural order of things is so upset, for he asks:

"Was it earthquake or tobacco,

Day of doom or night of drink?"

The truth of a belief is tested by seeking the object believed in. If the mystic defined God as the mystical experience itself, then the truth of the belief in God would be established when the experience was obtained. But God, for the mystic, is not the mystical experience itself. That is, God is not the experiencing, but the experienced. God is believed by the mystic to be real outside of the occasional mystical experiences, and to reveal himself in the experiences. God is believed to be, not the experience, but the giver of the experience, which is interpreted as an experience of union with God. There is attribution of the experience to a supernatural source. Without such attribution, the experience is not called a religious experience.

James argues quite unsoundly that the question of the origin of an experience is irrelevant. $\mathrm{He}$ says, "The plain truth is that to interpret religion one must in the end look at the immediate content of the religious consciousness." ${ }_{12}$ I would fully agree with this, since one essential component of the religious consciousness is the belief in some-

${ }^{12}$ Varieties of Religious Experience, p. 12, note. 
thing superhuman, but since such a belief is necessarily present in every religious experience, ${ }^{13}$ the question of the natural or supernatural origin of the emotional components of the experience is very relevant indeed.

James's whole argument against the validity of attaching any significance to the connection between religion and sex is rather weak. It is not because "language drawn from the sexual life"14 is common in religious literature that the psychologist interprets religion in terms of sublimation of sex. Much of religious literature is unreliable as scientific psychological evidence. This is shown by the fact, as James points out, that religion has often been described in terms of other instincts, more or less irrelevant. But it is just because religion is actually observed by modern psychologists to be correlated with sexual phenomena that a sexual origin is frequently ascribed to it.

What James really seems to be arguing for is the irrelevance, so far as truth and falsity are concerned, of ascribing to an experience a pathological, as opposed to a normal, physiological origin. $\mathrm{He}$ admits my contention that the question of physiological origin is relevant when "supernatural

${ }^{13}$ In the case of the mystical experience there is present, at least after the experience, the belief that an objective God was revealed.

${ }^{14}$ James op cit., p. II, note. 
origin is pleaded by the other side." 15 In the case of the religious experience, there is belief in a supernatural origin, as James himself insists. So in reality there is little disagreement in the last analysis between the views of James and the point that I am insisting on. James would admit the fallacy of false attribution when the question is one of attributing an experience to a supernatural source, by the one who has the experience, if psychologists can establish the physiological origin of the experience.

Mysticism may be identified with the metaphysical system that asserts the unity, timelessness, immediacy, and ineffableness of reality, together with the denial of reality to the phenomenal world. Royce defines it thus, and proceeds to refute it. ${ }^{16}$ Professor Hocking accepts ${ }^{17}$ Royce's refutation, but says that mysticism has been historically a much broader thing than the metaphysical system that Royce refutes. Professor Hocking says, "The agreement of the mystics lies in that fact, prior to doctrine, and wholly coextensive with religion, the practice of union with God in a special act of worship." ${ }^{18}$ But here is the rub. Here the whole question at issue is stated, in contradictory form.

${ }^{15}$ Ibid., p. I9. See also p. 520.

${ }^{10}$ The World and the Individual, Vol. I, Ch. II.

${ }^{17}$ The Meaning of God in Human Experience, p. $35 \mathrm{I}$.

${ }^{18}$ Ibid., p. 352 , 
"The practice of union with God in a special act of worship" is not a "fact, prior to doctrine," as Professor Hocking says it is. It is rather the doctrinal interpretation of a fact. The fact is the experiencing. The doctrine is, that something objective, God, is experienced.

I would agree that the mystic's worship is an attempt to gain what the worshipper believes is union with God; but, so long as science and scientific methods are accepted, there is a presumption against the truth of the belief. The mystic commits the fallacy of false attribution. The source of his experience is "within" and not "without." The experience is a form of emotionalism, which consists of visceral reverberations and the activity of the sympathetic nervous system.

Professor Leuba has made a psychological study of mysticism, ${ }^{19}$ and his conclusion is that mysticism is, to a large extent, a form of sublimated love. This is the conclusion of the Freudians. Professor Coe gives a good criticism of mysticism. $^{20}$ He denies that anything objective is revealed in the mystical experience itself, and says that the objective factor is added when the experience is interpreted. The cause of the interpreta-

${ }^{18}$ See "On the Psychology of a Group of Christian Mystics," Mind, N. S., Vol. XIV (1905), pp. 15-27.

${ }^{20} \mathrm{G}$. A. Coe, "The Sources of the Mystical Revelation," The Hibbert Journal, Vol. VI (1907-08), pp. 359-372. 
tion made does not reside in the nature of the experience itself; but "tradition and instruction, autosuggestion grown habitual, and reflective analysis," ${ }^{21}$ determine the interpretation of the mystical experience as a revelation of God. "The mystic brings his theological beliefs to the mystical experience; he does not derive them from it." ${ }_{22}$

Though the half-way mysticism of most mystics is inadequate, and involves the fallacy of false attribution, it is still possible that there may be a mystical solution of the religious problem. So long as any recognition is given to phenomenal reality and to the world that the sciences study, mysticism must be regarded as emotionalism only, with a false belief as to the source of the emotion; but a complete metaphysical mysticism, such as Royce expounds and refutes, may still be the truest insight, and farthest from a final refutation. Thoroughgoing mysticism is at least wonderfully attractive, occasionally for all reflective persons, and always for a few; and it will continue to lure world-weary souls to the promised rest and peace of its Nirvana. ${ }^{23}$

${ }^{n}$ Ibid., p. 367.

${ }^{29}$ Ibid., p. 367.

${ }^{23}$ For a further discussion of the fallacy of false attribution, see the author's article, "The fallacy in Mr. H. G. Wells's 'New Religion," in the Monist, Vol. XXVIII (I918), pp. 604-08. 


\section{CHAPTER III}

\section{A CLASSIFICATION OF RELIGIOUS VALUES ${ }^{1}$}

$\mathbf{T}^{\mathrm{N}}$ an article in the Journal of Philosophy, I Psychology, and Scientific Methods ${ }^{2}$ I pointed out two fallacies that are met with frequently in works in the philosophy of religion, fallacies that I have called the pragmatic fallacy and the fallacy of false attribution. Professor Brightman, ${ }^{3}$ Professor Moore, ${ }^{4}$ and Dr. Schiller ${ }^{5}$ have presented criticisms of my views. In answering these criticisms I shall be led into a somewhat detailed discussion of religious values from the point of view of a behaviorist. The views of one who speaks of the meaning and value of God in human behavior are apt to be misunderstood, since religion is a field into which behaviorism has not as yet ventured far. However, since this is a direction in

${ }^{2}$ Reprinted, with slight changes and additions, from the Journal of Philosophy, Psychology, and Scientific Methods, Vol. XV (I918), pp. 488-99, where the article appeared under the title, "On Religious Values: A Rejoinder."

${ }^{2}$ Vol. XIV, pp. 653-660. This article is reprinted above as Chapter II.

Journal of Philosophy, Psychology, and Scientific Methods. Vol. XV, pp. 71-76.

${ }^{4}$ ibid., pp. 76-78.

'Ibid., pp. 505-515. In the following chapter I take account of Dr. Schiller's criticism. 
which study will prove fruitful, I shall offer a classification of religious values, which will make clearer what would be an objective, behavioristic account of religious values, and which will also be a part of my answer to my critics.

The pragmatic fallacy in the philosophy of religion, as I have defined it, consists of the identification of the value with the truth of religious beliefs, and of the acceptance of those religious beliefs as true which are found to have value. I have insisted that the concepts of truth and of value can not be identified. I have pointed out especially that the survival value of religious beliefs in human evolution is no evidence for the truth of the beliefs, contrary to the view of James, who was the first to employ Darwinism in defense of religious truth. Further discussion of the meaning of value is obviously needed, but I presupposed among the readers of my article a sufficient familiarity with the developments in the theory of value from the work of Meinong ${ }^{6}$ and of Ehrenfels ${ }^{7}$ to recent discussions to obviate such

'A. Meinong, Psychologisch-Ethische Untersuchungen zur Werttheorie, Graz, I894.

${ }^{\prime} \mathrm{C}$. von Ehrenfels, System der Werttheorie, 2 vols., Leipzig, 1897. 
misinterpretations as have been made of my statements by Professor Brightman.

Though the pragmatic fallacy may be maintained equally well in connection with other theories of value, the theory which I accept, as I suggested in my original article, is one which defines value in terms of organic attitudes and acts, in terms of liking and desiring; and liking and desiring may be most adequately treated in behavioristic terms. An object possesses value if some organism has an interest in it; and to have an interest in an object means to act in such a way as to try to get possession of it (or retain it if already possessed), or at least to enjoy it, as in the case of esthetic values. Since interests and likes and dislikes have meaning only in terms of behavior, value may ultimately be defined in terms of reactions or responses, positive or negative. Positive response constitutes positive value (the good, the desirable, etc.), and negative response constitutes negative value (the bad, the undesirable, etc.).

But value is not so simple and obvious a thing as such a definition might seem to imply. There are various types and classes of values all coming within this one definition. I might have presupposed that my readers would be familiar with the common distinction between independent, or immediate, values, attaching to objects valued for 
their own sake, as ends, and dependent, or instrumental, or derived, values, attaching to objects only when such objects are instrumental to other objects possessing independent values. Instrumental values are "derived" from the relation of the objects to other objects directly valued. An instrumental value may thus be only indirectly the object of interest. Though I might have presupposed familiarity with such a distinction between independent and dependent values, I was careful to state that biological utility is a case of what I have here called instrumental value, not, independent, since an object that possesses biological utility, $i . e$., one that is instrumental to the preservation of life, "is indirectly the object of interest or desire, since life is valued with approximate universality." But Professor Brightman overlooked my statement of this distinction, and tries to make out that I have presented two definitions of value, a psychological and a biological one. My single definition is, rather, a psycho-biological one, and allows for the distinction between independent and dependent values. The classification which I shall present a little later will make my position clearer.

Professor Brightman makes two confusions of the issue when he refers to my distinction between

'Loc. cit., p. 72. 
46 The Biological Foundations of Belief

what I called "scientific" and "metaphysical" beliefs. I said that "scientific" beliefs, referring to details of the physical environment and capable of empirical verification, must be true in order to be valuable. I cited the case of belief in the safety of the ice as an example. Professor Brightman, ${ }^{9}$ in the first place, confuses the belief in the safety of the ice (the belief is a psychological entity-ultimately a behavioristic fact) and the ice itself. I spoke, not about the value of the ice, but only about the value of the belief in the safety of the ice. Whether or not the small boy likes the ice itself is an extraneous matter. In the second place, as I pointed out, it is the indirect or instrumental value of the belief (its instrumentality in relation to survival, survival being directly desired) that is in question, not its independent value as the direct object of desire, as Professor Brightman seems to think. ${ }^{10}$ So whether or not the small boy likes to believe in the safety of the ice is also an extraneous matter. The actual instrumentality of the belief is the important thing.

As a result of these two confusions, Professor Brightman's criticism of my statement of the pragmatic fallacy falls down. When he concludes that he has reduced my pragmatic fallacy to "the

See loc. cit., pp. 71, 72.

${ }^{20}$ Loc. cit., p. 72. 
argument that a belief is true because we desire it to be true," 11 he shows his entire failure to take into account the distinction between independent and dependent values. The chief error of some pragmatists when dealing with the philosophy of religion, and of James especially, has been in maintaining that religious beliefs possessing survival value thereby demonstrate their truth. Such beliefs may or may not be true. Nothing can be inferred from their survival value as to their truth. To maintain that survival value of religious beliefs is evidence of their truth is to commit the pragmatic fallacy.

Professor Moore objects to my distinction between "metaphysical" and "scientific" beliefs. He says ${ }^{12}$ that even false "scientific" beliefs may be subjectively valuable, as in the case of belief in the non-existence of pain, while being objectively harmful through hindering the cure of the disease. This is all very true, and does nothing to invalidate the distinction that I made. It helps to confirm it instead. The fact is, as Professor Moore points out in this example, that "scientific" beliefs do have objective effects, and hence must be true if, in the long run, they are to possess a balance of positive value. "Metaphysical" be-

\footnotetext{
${ }^{11}$ Loc. cit., p. 72.

${ }^{22}$ Loc. cit., p. 77.
} 
liefs, on the other hand, as I defined them, can not have objective effects to counterbalance any subjective effects of positive value that they may have. Professor Moore does not deny this, but simply claims that they may have harmful effects on "the spiritual nature." This is beside the point when the case is being argued on the biological grounds of pragmatism, for "the spiritual nature," in Professor Moore's sense of the term, does not count as a factor of biological significance in the struggle for existence.

It is necessary to make the distinction that I did between "scientific" and "metaphysical" beliefs or else, from the premises of the instrumentalist, it would follow that all beliefs that survive would be true, and that survival would be the test of truth. I pointed out that some beliefs, which I called "metaphysical," in that they do not refer to the physical environment, may possess a subjective ${ }^{13}$ value even if not objectively true, and may prevail and survive because of this subjective value, while false "scientific" beliefs lead in the end to bad objective results that destroy the beliefs.

\section{II}

Having defined value in its generic sense in

"For behaviorism the term "subjective" lacks its usual connotation. It has a legitmate use and meaning, however, referring to one phase of the objective mental processes. 
terms of interest or desire, it remains for us to differentiate religious values from other values, such as ethical, economic, and esthetic values, and then to classify the religious values. Religious values may be differentiated from the values dealt with by the other value sciences by reference to the objects to which they are said to attach, i. e., to the supernatural objects of belief, to the acts of worship that such belief leads to, and especially to the beliefs themselves, regarded as psychological objects, and to emotional states associated with the beliefs.

The distinction between immediate and instrumental values, and that between real and ideal values, are the chief ones to be pointed out in a classification of religious values. Immediate and instrumental values have already been defined. Ideal values are those which we predicate of objects which are not real, but which depend for their existence on the valuing subject, being "invoked by an interest and held in existence only by the act of imagination." ${ }^{14}$ Real value-objects, on the other hand, are objects that exist independently of the interested subject. They are facts, while ideal value-objects are fancies.

My classification of religious values, which fol-

\footnotetext{
${ }^{14}$ R. B. Perry, "Religious Values," American Journal of Theology, Vol. XIX (I915), p. 3.
} 
50 The Biological Foundations of Belief

lows, is in general agreement with one already made by Professor Perry, ${ }^{15}$ but I have made several added distinctions to allow for cases of value that could not otherwise be provided for.

Instrumental values are of importance in the study of value, especially in the case of religious values. There are several distinguishable sorts of instrumental values. The mere causal connection between two objects, one of which is directly valued, is one case. I refer by this to the relation of $A$ to $B$ when $A$ is the condition of $B$ 's occurrence or existence. A second case is that involving the judgment that $A$ is the condition of $B$, when the judgment is true. A third case is that in which there occurs the judgment that $A$ is the condition of $B$, when the judgment is false, though $A$ is real. A fourth case involves the judgment that $A$ is the condition of $B$ when $A$ is unreal, though believed real, but such that the judgment would be true if $A$ existed. A fifth case is that involving the judgment that $A$ is the condition of $B$ when $A$ is unreal, and when the judgment would be false even if $A$ existed.

In these five cases we find, first, the distinction between actual causal connection and the judgment of, or belief in, such connection; second, the distinction between true and false judgments of

${ }^{18}$ Loc, cit., pp. Iff. 
causal connection when truth and falsity depend upon the reality or unreality of the causal connection; and, third, the distinction between true and false judgments of causal connection when truth and falsity depend upon the existence or nonexistence of $A$. A combination of the second and third cases occurs when $A$ is valued because judged instrumental to $B$, and when, as a matter of fact, $A$ is unreal, and when, further, the relation of instrumentality could not hold even if $A$ existed.

The mere relation of causality or instrumentality in itself does not constitute value $;^{16}$ but we may say that an object has value if it is actually instrumental to a ralued object, even though the instrumentality is not recognized. If $A$ is actually instrumental to $B$, and if $B$ is the object of desire, then it is permissible to say that $A$ has conditional, instrumental value. The biological value of many religious beliefs is of this sort. In such a case the object $A$ is not the object of an actual interest, but it would be desired if its instrumentality to $B$, which is desired, were recognized.

All of the above distinctions are provided for in the three following tables:

${ }^{10}$ See W. T. Bush, "Value and Causality," Journal of Philosophy, Psychology, and Scientific Methods, Vol. XV, pp. 85-96. 
52 The Biological Foundations of Belief

I. Real Values (attaching to objects that exist).

I. Immediate, or independent (attaching to objects valued directly).

2. Instrumental, or dependent.

$A$. Conditional (when real instrumentality exists, but is not recognized).

$B$. Actual (when instrumentality is recognized).

a. True (when valuing of object is mediated by a true judgment of instrumentality).

$b$. False (when mediated by a false judgment).

What I call "conditional, instrumental values" are in all cases actually instrumental, by definition. They are not actual values, however, because not valued in the absence of a judgment of instrumentality, which is required to convert a mere disposition into an actual valuing act. What I call "actual, instrumental values" may not be actually instrumental in all cases; but if judged to be instrumental, whether truly or falsely, they then have actual value because actually desired.

A second table, of ideal values, would be as follows :

II. Ideal Values (attaching to objects that are not real).

I. Immediate, or independent. 
2. Instrumental, or dependent.

A. Conditional (lacking, for what does not exist can not be the cause of anything). B. Actual.

a. True (lacking, for there can be no true judgment of instrumentality when the instrument does not exist).

b. False (the only case of instrumental ideal values).

In the case of a false, actual, instrumental, ideal value, the object is actually valuable because it is ( I) believed real (falsely), (2) judged instrumental (falsely), and (3) actually valued because so judged.

A third table, of the real values of belief, is necessary. For behaviorism belief is a positive reaction to a proposition, and disbelief is a negative reaction. Belief in God, for example, is an acceptance of, or a positive organic attitude towards, the proposition, God exists. Disbelief is a rejection of, or a negative attitude towards, the proposition. Beliefs are psychological, $i$ e., behavioristic, entities, and propositions are not. Strictly, when such a distinction is made, it is only propositions that may be true or false, while beliefs are only positive or negative. But common usage justifies one in call- 
ing a belief in a true proposition a true belief, and a belief in a false proposition a false belief. Furthermore, disbelief in a true proposition would bc the equivalent of a false belief, though disbelief in a false proposition might, or might not, be the equivalent of a true belief. For the purposes of the theory of knowledge, the terms "belief" and "judgment" are practically interchangeable. In the philosophy of religion, however, I prefer the term "belief," since it suggests a more permanent and stable reaction of the organism.

In the case of objects merely imagined, but believed to be real, the objects of belief are unreal, but the beliefs themselves, as psychological subject-matter, are real. So there would be a third table of real values, like the first table except for the limitation of the objects to beliefs themselves :

\section{Real Values of Belief}

I. Immediate, or independent (when one believes, and likes to believe, just for the sake of believing, if there be such a case).

2. Instrumental, or dependent.

$A$. Conditional.

$B$. Actual.

a. True.

b. False.

These tables of values may be further eluci- 
dated through application to the chief religious objects in the higher religions. According to James's psychological study of the actual religious experiences of individuals of strongly marked religious character, ${ }^{17}$ the chief objects of religious interest and belief in the higher forms of religion are the following four: (I) God, as a more or less personal being; (2) human souls as real and significant; (3) the permanent significance of the human soul, i.e., personal immortality; and (4) freedom (though not, to be sure, in all forms of the higher, redemptive religions), or rather indeterminism, since the term "freedom," from its philosophical associations, means, according to James, "soft determinism," 18 which is still genuine determinism even though "softened" by its ideal. istic setting.

God is the chief object of belief in most forms of the higher religions. Buddhism is no exception, for in actual practice Buddhism is not atheistic, the Buddha himself being deified; and in the more philosophical form of Buddhism the law of Karma, which is the moral order of the universe, would pass for a god. "Some outward real-

${ }^{17}$ See The Varieties of Religious Experience, and The Will to Believe.

${ }^{18}$ See Ch. V, "The Dilemma of Determinism," in The Will to Believe. 
56 The Biological Foundations of Belief

ity," James says, ${ }^{19}$ "of a nature defined as God's nature must be defined, is the only ultimate object that is at the same time rational and possible for the human mind's contemplation." As to the nature of God, James say: "It is essential that God be conceived as the deepest power in the universe: and, second, he must be conceived under the form of mental personality. ... God's personality is to be regarded, like any other personality, as something lying outside of my own and other than me, whose existence I simply come upon and find. A power not ourselves, then, which not only makes for righteousness, but means it, and which recognizes us." ${ }^{20}$ God, regarded as a personality, is obviously desired as an end, like a human personality, and not merely as a means. In the higher religions God is actually so regarded, though no counterpart of this is discoverable in the lower, nature religions.

God would, however, if he existed, be also a means to other ends. He would guarantee the realization of the highest human ideals. First of all, he would guarantee personal immortality, which, according to James, "is one of the great spiritual needs of man." ${ }_{21}$ "The difference in natural 'fact' which most of us would assign as

${ }^{19}$ The Will to Believe, pp. 115, 116.

${ }^{20}$ Ibid., p. 122.

${ }^{21}$ Human Immortality, p. 2. 
the first difference which the existence of a God ought to make would, I imagine, be personal immortality. Religion, in fact, for the great majority of our own race means immortality, and nothing else. God is the producer of immortality; and whoever has doubts of immortality is written down as an atheist without further trial." 22

The human soul is an object of vital concern in most forms of the redemptive religions. For example, in orthodox Christianity it is the sinful soul that needs salvation, and the Buddhist salvation from rebirth is meaningless unless there is a soul that is reincarnated, though Buddhism tries to deny the reality of the soul while still believing in reincarnation.

Although a belief in and a desire for indeterminism are not universal in the higher forms of religion, James classes indeterminism among man's "spiritual" needs. It enhances the significance of the self. The mechanical chain of events in a naturalistic scheme, which denies individual initiative, fails to satisfy, according to James, the actual desires of most persons. The "soft determinism" of monistic idealism also denies any real individual creativeness in the act of choice. For absolute idealism, "our wills are [not] ours, to make them Thine;" they are only "Thine." Plu-

"The Varieties of Religious Experience, p. 524. 
ralistic idealism of some sort would seem to be what the majority of the religious portion of humanity desires. There is a prominent exception, Calvinism, which denies indeterminism; but James speaks of the unsatisfactory character of Calvinistic doctrine for most religious persons, and says, "A God who gives so little scope to love, a predestination which takes from all endeavor all its zest with all its fruit, are irrational conceptions, because they say to our most cherished powers, There is no object for you." ${ }^{23}$

It now remains to classify the above-named objects of religious belief in respect to the sorts of value attaching to them. God, regarded as real, would have, first of all, an independent, or immediate, value in the higher religions. For all forms of mysticism the ultimate cosmic reality possesses immediate value. God would satisfy the believer's intellectual curiosity as to the first principle of the universe, his social desire for a great Friend above all human friends, and perhaps his esthetic interest. God would also have an instrumental, real value by guaranteeing the final attainment of the goal of man's highest endeavors. When St. Augustine prays, "I seek Thee in order that my soul may live," God is regarded by him as having instrumental value; and then, when St. Augustine

${ }^{23}$ The Will to Believe, p. 126. 


\section{$A$ Classification of Religious $V$ alues}

speaks of God as the supreme good, the object of his belief is invested with immediate value. God, if real, would always have at least conditional, instrumental value, being always instrumental in some direction; and would possess actual, instrumental value when actually valued because judged instrumental. The judgment that mediated the valuing might be either true or false, for, though God is assumed in this classification to be real, the believer might judge him instrumental in cases where the relation of instrumentality did not hold.

It is doubtful whether the soul ever possesses immediate value, unless it is in the case of some ideal of future selfhood that one desires to realize. In such a case the "ideal" future self would be regarded as real, and hence possessing a real, immediate value, since it is assumed in this classification to be realizable sometime, while the ideal values of Table II are assumed to be purely imaginary and never realizable. The soul, however, is more important for the instrumental value attaching to it, as a condition, e. g., of immortality. Personal immortality probably never possesses immediate, real value, but is only instrumental to the rejoining of departed friends and to the fulfilment of those purposes that death, if final, leaves incomplete. Indeterminism has only instrumental value, being a means to the desired freedom of 
choice. The soul, freedom, and immortality, regarded as possessing instrumentalvalue, would possess only conditional value in certain cases, when actually instrumental, but not recognized as such; and actual value in other cases when actually valued because either truly or falsely judged instrumental.

So far I have assumed for the purposes of my classification that the religious objects in question are realities. If assumed to be unreal, they would be classified differently, in Table II. God, if unreal, would possess ideal, immediate value if believed in and valued directly. Being assumed unreal, God could not be actually instrumental. Hence he could never have what I have called conditional, instrumental, ideal value. He could have actual, instrumental, ideal value, however, when judged, falsely, of course, to exist, and to be instrumental to desired ends. The soul, immortality, and indeterminism would not possess immediate, ideal values except in the one possible case of the soul, corresponding to the immediate, real value of the soul as noted above. Of the instrumental ideal values, false, actual, instrumental values are the only ones that these objects could possess.

The determination of the reality of the objects of religious beliefs is a metaphysical problem. 
Whether or not such objects are real, however, it is a fact that there exists in many persons belief in religious objects. Therefore I shall now classify in Table III the real values of religious belief, regarded as a psychological, or behavioristic, object, and viewed apart from the objects of belief.

Belief could hardly possess immediate, or independent, value, except in the case where one believes in God, and likes to believe, just for the sake of believing, were there such a case. Though it is true that probably all religious believers are glad that they believe, still for most people the liking to believe in God is not a sufficient basis on which to adopt the belief. Believers normally believe in God because they think he exists; though they may as an afterthought value their belief, and pity the unbelief of others. The more significant values of religious belief, however, are instrumental values.

The most important instrumental value of belief in the higher religions is of a moral sort, even in the redemptive religions that are beyond the stage of the religions of the law. Religious belief is instrumental in many cases to higher standards of personal conduct than would otherwise be attainable. A further value is the hygienic, or therapeutic, value of religious belief. This again is a case of belief possessing instrumental, real value. 
If belief in God makes one happy, and if one likes to be happy, then religious belief is a real means to this end. If, through making one happy, religious belief benefits one's health, and if one values good health, then again belief has an instrumental value. In the case of belief both as hygienic and as moral in its effect there is real instrumentality, and theiefore belief possesses real value in such cases-value of the conditional sort when the instrumentality is not recognized. When the instrumentality is recognized, and when the belief is actually prized on that account, then the belief has true, actual, instrumental value; and a belief would have false, actual, instrumental, real value when actually valued because judged instrumental to something of which it was not actually a condition. It is chiefly through the moral and the hygienic effects of religious beliefs that they come to possess survival value, and to be an important factor in the struggle for existence.

There are other religious values that deserve mention, such as the instrumental, real value of psychological states of imagination induced by religious belief and worship, of emotional states peculiar to religious experiences, and of the overt acts of worship that are the outcome of religious belief. (I) The play of imagination, when the theme is exalted, as in religion, helps the mundane 
consciousness to escape from the provincialism of its ordinary environment, and lends enchantment to the commonplace experiences of life. (2) Religious emotional states may possess positive, instrumental, real value, though there is always danger that their value may be negative. Mysticism may be regarded psychologically as a state. of emotionalism, and as such it may possess positive, instrumental, real value. Santayana says of it," "Although mysticism, left free to express itself, can have no other goal than Nirvana, yet moderately indulged in and duly inhibited by a residuum of conventional sanity, it serves to give a touch of strangeness and elevation to the character and to suggest superhuman gifts." The negative value of religious emotionalism appears, for example, in the possibility of gross sensual excess following upon revivalistic excitement. (3) The overt acts of worship in many cases possess positive, instrumental, real value of a social sort through producing concerted action and thereby strengthening social bonds.

The question arises as to the value of religious Truth. Truth, usually spelled with a capital "T," is often identified with ultimate reality, the goal of all striving, etc., as in Lowell's "Commemoration Ode":

${ }^{24}$ Poetry and Religion, p. I8. 
"Many loved Truth, and lavished life's best oil Amid the dust of books to find her,

"So loved her that they died for her, Tasting the raptured fleetness

Of her divine completeness."

Truth that possesses "divine completeness" is not truth in any epistemological or logical sense of the word. The poet in the above passage is not singing praises to the consistency or coherence among judgments, or to the pragmatic "working" of be. liefs, or to the correspondence between propositions and facts. "Truth," as the word is often used by poets and preachers, is more or less synomymous with "God," and consequently its values would be the same as those ascribed to God in the above classification.

\section{III}

Returning now to the pragmatic fallacy, we see that it relates chiefly to what I have called the conditional, instrumental, real value of religious belief. The survival value of religious belief is a case of conditional, instrumental value, except in those cases where the biological utility of belief is recognized, and where the value becomes actual as value. The valuable belief need not have a "conscious relation to biological survival," as Professor Brightman seems to think, ${ }^{25}$ in order to

${ }^{25} \mathrm{See}$ loc. cit., p. 72. 
come within the category of values. The instrumentality to a directly valued object is the essential thing. The pragmatic fallacy consists chiefly in passing from the conditional, instrumental value of a belief to the truth of the belief, and in arguing that a belief, because possessing survival value, must, therefore, be true.

Both Professor Brightman and Professor Moore criticize what I have called the fallacy of false attribution, the fallacy of attributing the religious experience, so called, to "higher," supernatural forces in cases where the experience is merely physiological in source-where it is from: "below" and not from "above." Professor Brightman says that "it is rigorously logical to say that an event has a psycho-physiological cause, and also that the event is a divine act." ${ }^{26}$ Similarly Professor Moore says:27 "The alternative is not-Are these experiences subjective or objective, physiological or divine? . . . Rather, the question is, Are they also objective and spiritual?" Both would maintain, as Professor Brightman explicitly does, that every event "is a manifestation, an expression, an act of the divine," and that "Kipling's camel-'jims' were divinely caused." 28 The difficulty with such a view

\footnotetext{
${ }^{20}$ Loc. cit., p. 76.

"Loc. cit., pp. 77, 78.

"Loc. cit., p. 76 .
} 
is that if every event is called divine, then the term "divine" ceases to have any meaning at all, and argument about it becomes useless. It then becomes impossible to single out a field occupied by religion. That which applies to everything elucidates nothing. Moreover, belief in the universe as explained in the naturalistic terms of scientific evolutionism is not a religious belief, and can not be made into a religious belief simply by substituting the term "God" for the term "physical universe." I submit that any religious individual would cease to regard himself as religious, and in fact would cease to be religious, if he came to accept the naturalistic explanation of his socalled religious experiences.

Professor Moore admits that "the belief that God is experienced is a doctrinal interpretation of mystical experiences," ${ }^{29}$ not a fact, but the interpretation of that fact. He says, however, that "precisely the same thing is true of physical experiences." 30 But, granting this, we are confronted with the fact that the naturalistic interpretation of human experience, if accepted, contradicts the religious interpretation to the extent that, if the person having the "religious" experience gives to it a naturalistic interpretation, his former reli-

\footnotetext{
${ }^{20}$ Loc. cit., p. 78.

${ }^{30}$ Loc. cit., p. 78.
} 
gious reading of the events becomes psychologically impossible.

Criticism of the pragmatic fallacy and the fallacy of false attribution that would undermine them must first meet them on their own ground. As I originally defined them, and as I still maintain them, they stand as genuine and frequently encountered fallacies in the logic of religion. 


\section{CHAPTER IV}

ON TRUTH AND SURVIVAL VALUE ${ }^{1}$

$D_{\text {Value,", illustrates a characteristic of philos- }}^{\text {R. SCHILLER'S article, "Truth and Survival }}$ ophy found throughout its history, the characteristic, namely, of emphasis upon minor differences of view while important points of agreement are left unnoticed. The history of philosophy consists so largely of arguments and contradictions that philosophers easily acquire the habit of looking for disagreement rather than for agreement. My own point of view in philosophy is fundamentally much like Dr. Schiller's. I have been influenced in the development of my own ways of thinking by none more than by James, and by Dr. Schiller himself; and, though there may be unquestioned differences, as, for example, between Dr. Schiller's subjectivism and my own behavioristic views, still the habit of regarding all human questions from the biological point of view constitutes an important initial point of agreement. In Dr. Schiller's

\footnotetext{
${ }^{1}$ Reprinted, with change of title, from the Journal of Philosophy, Psychology, and Scientific Methods, Vol. XVI (1919), pp. 259-71.

${ }^{2}$ Journal of Philosophy, etc., Vol. XV, pp. 505-15.
} 
criticism $^{3}$ of what I have called the pragmatic fallacy, ${ }^{4}$ I feel that much of the difficulty and disagreement is largely verbal. Indeed, our essential agreement on an allied subject is shown in the last part of Dr. Schiller's article, where he has applied biological categories in considering the question of pessimism in a manner precisely parallel to my own treatment of this question in an article ${ }^{5}$ that was in press when Dr. Schiller's article appeared.

In the present chapter I wish to discuss further the question of the biological foundations of human belief. My procedure will, in the main, be in exact agreement with Dr. Schiller's and with James's approach to the question of belief. The question of the relation of truth to survival value, however, will eventually arise. As Dr. Schiller says, ${ }^{6}$ "The matter cries out for further investigation." In considering the matter I shall attempt to make clear the real point of difference between my own view as already stated and that of pragmatism of the Jamesian type, a type now represented by Dr. Schiller.

\section{I}

Darwinism has been one of the most fruitfui

${ }^{3}$ Loc. cit.

${ }^{4}$ See Chapters II and III, above.

"The Biological Value of Religious Belief," American Journal of Psychology, Vol. XXIX (1918), pp. 383-92. Reprinted above as Chapter I.

${ }^{\circ}$ Loc. cit., pp. $514,15$. 
sources of pragmatism. After Darwin had convinced the world that man in his physical aspect is part and parcel of the animal kingdom, James extended Darwinian principles to the human mind, showing how mental processes can be understood, so far as their origin and their present operation are concerned, only when placed against an evolutionary background in which natural selection of useful variations has been a vera causa in the mind's development. Present-day behaviorism is one of the consistent conclusions of the biological trend in psychology which was given so strong an impetus by the publication of James's Principles of Psychology and other psychological treatises. It has been a short step from James's "The Child as a Behaving Organism,"7 for example, to present-day behaviorism.

Many of James's later philosophical views consist fundamentally of an extension of Darwinian principles from psychology to the larger probiems of philosophy; and Dr. Schiller's "Axioms as Postulates," and some of his other writings, show as vividly as anything in the literature of pragmatism the biological point of view in relation to philosophical questions. But, whereas Dr. Schiller represents a development of pragmatism in a sub-

\footnotetext{
${ }^{7}$ This is contained in the volume, Talks to Teachers, Ch. III. ${ }^{8}$ Published as Ch. II of Personal Idealism, edited by $\mathrm{H}$. Sturt.
} 
jectivistic direction, behaviorism may be shown to be a more logical development of James's views. So long as the mental life is regarded as somehow subjective in the literal sense of the term, a completely biological treatment of the mind is impossible. When, on the other hand, consciousness and behavior are identified, as in Professor Holt's view, ${ }^{\circ}$ for example, so that to be conscious means to respond specifically to an object as the result of external stimulation, while the content of consciousness is the external object responded to, it becomes easy to be thorough-going in a biological account of mental life. The consciousness of man, no less than that of the amœba, may be treated objectively, in terms of stimulus and response. Mental variations which have proved useful in the struggle for existence, and which have been preserved through the operation of natural selection, are simply, in their physical context, ${ }^{10}$ useful modes of behavior.

For behaviorism, beliefs are not subjective entities, but objective processes. A belief is an organic response. The physical presupposition of belief is a system of reflex arcs so integrated that

"See E. B. Holt, The Freudian Wish, especially the supplement, "Response and Cognition"; also The Concept of Consciousness.

${ }^{10}$ See James, Essays in Radical Empiricism, Chs. I and II, for an unsurpassed discussion of the distinction between the mental and the physical. 
some given assertion or proposition may be responded to positively. A belief is an acceptance or an affirmation of a proposition, and may be either an actual response, or, in the absence of the proper stimulus, a mere organic set or disposition. Thinking, likewise, which is one of the means by which beliefs are arrived at, is not an ethereal process occurring in a vacuum, but is a process consisting of responses of the animal type. Professor Watson has discussed the thinking process in terms of implicit behavior in which incipient responses of the tongue and vocal organs play a prominent part. ${ }^{11}$ Professor Thorndike has given a more extended account than Professor Watson's of the higher thought processes in terms of behavior. ${ }^{12}$ Professor Dewey ${ }^{13}$ has analyzed the complete act of thought into responses which he calls habits, not "automatic routine habits," but "habits of reflective consideration." ${ }^{14}$ Thinking, according to Professor Dewey's analysis, consists of locating and defining a recognized difficulty, suggesting a possible solution, finding the implications of the suggested solution, and testing this possible solu-

\footnotetext{
${ }^{11}$ J. B. Watson, Behavior, pp. 18, 19, 324-28; Psychology, Ch. IX.

${ }^{12} \mathrm{E}$. L. Thorndike, Educational Psychology, Vol. II, The Psychology of Learning, Ch. IV, especially pp. 46, 47.

${ }^{13}$ John Dewey, How We Think, Ch. VI.

${ }^{14}$ See John Dewey, "Public Education on Trial," New Republic, December 29, 1917, p. 246.
} 
tion, or hypothesis, through observation of the facts. These operations are all habitual responses no different in kind from the simpler animal responses. They are perfectly definite and objective, and may be treated wholly in behavioristic terms.

Belief, as I have said, consists either of an actual response or of an organic attitude. Belief is a positive attitude or response, as, for example, the belief in the Copernican theory, which manifests itself in an acceptance of the proposition asserting the theory in question. Disbelief is a negative response, a rejection. Doubt is an unstable reaction, not definitely positive or negative. A proposition, on the other hand, is not a response. It is, first of all, a group of words, which, as words, are marks on paper or sounds in the air. Words have meaning, however, which can ultimately be stated, perhaps, only in terms of universals. However this may be, a proposition, in the first place, is not psychological subject-matter; and, secondly, it is of propositions that truth and falsity are properly predicable. We are justified by common usage, nevertheless, in speaking of true and false beliefs. A true belief is really a positive reaction to a true proposition. A false belief is primarily a positive reaction to a false proposition, though a negative response to a true proposition would be the equivalent of a false belief. 
So far as questions of positivity and negativity in the behavioristic sense, and truth and falsity in the logical sense, are concerned, "belief" and "judgment" are practically interchangeable. Belief is a more sustained response, or a more permanent organic disposition or attitude, than judgment, but for most purposes we may use the terms interchangeably without serious error.

\section{II}

After these preliminary statements, showing the point of view from which I wish to look upon the question of belief, I am able to pass directly to a consideration of the biological grounds of some of the actual beliefs which have been held in the course of history, and which are held at the present time. I have in mind especially beliefs of a more or less philosophical and religious nature; for such beliefs have been biologically conditioned in numerous important and interesting ways.

The student of such a problem will do well to keep his own philosophic beliefs in the background as much as possible. An impartial observation of just what actual beliefs have been held is what is desired, not a crit cism of these beliefs because of their possible falsity. The scientific attitude of the observer who is himself detached from the processes he is observing, is assumed by 
the behaviorist, whether he is studying animal behavior, the simpler human mental processes, or the more complex intellectual processes of man. The scientific attitude is one of impartial observation of facts, whether the facts are agreeable or not to the observer; and the behaviorist attempts, first of all, to make the study of the mind scientific. The scientist, through the development of a rigid experimental method, seeks to rule out subjective preferences and to be guided by the facts as the sole test of truth. As Mr. Russell has well expressed it, "The scientific attitude of mind involves a sweeping away of all other desires in the interests of the desire to know-it involves suppression of hopes and fears, loves and hates. and the whole subjective emotional life."15

Very few persons, however, ever develop the scientific attitude in its full purity. People in general are unconsciously influenced in their decisions and beliefs by their likes and dislikes, by their "subjective emotional life." James has given classic expression to this truth in his Will to Believe. He has asserted ${ }^{16}$ that man's passional nature decides for him doubtful questions that bear intimately on his life. Not only popular beliefs, moreover, but also the views of philosophers, are

${ }^{16}$ Bertrand Russell, Mysticism and Logic, p. 44.

${ }^{20}$ The Will to Believe, p. Ir. 
in some instances determined by the "will to be. lieve." The impersonal mathematical and laboratory methods of science can not easily be applied to the solution of the issue between idealism and naturalism, for example; and undoubtedly inherited or acquired emotional attitudes towards life have been the deciding factor in the trend of thought of many a philosopher. That the judgment of the average man, untrained in the niceties of scientific method, is influenced by desires and aversions, is so obvious that it needs only to be stated to be accepted; while James has maintained of philosophers that temperament really determines the acceptance or rejection of philosophic systems. Bradley has said similarly that the efforts of philosophers have been exerted for the purpose of finding reasons to justify what is believed instinctively.

The biological foundations of belief may be exhibited in two ways. In the first place, it may be shown in what manner some of the human instincts, which are the basis of man's emotions and desires, actually determine his beliefs. Since the instincts exist as one outcome of the biological struggle for existence, they rest upon biological foundations. In the second place, attention may be called to the direct survival value that beliefs possess through their subjective effects upon the physical economy of life. 
How the instincts influence belief may be illustrated by reference to the instincts that form the subjective support of religious belief. The biological basis of religious belief is similar to that of a wide variety of other beliefs. I shall draw principally upon Mr. McDougall's admirable study of the human instincts. ${ }^{17} \mathrm{Mr}$. McDougall's classification of the instincts is somewhat artificial and arbitrary. Man's nature resists any such precise analysis as he has made. His general attitude towards human behavior, however, is above criticism; and we can fall into no very serious error if we accept, for practical purposes, his list of instincts and emotions.

Mr. McDougall expresses accurately the attitude that we should take in examining the biological grounds of belief, when he says: "Mankind is only a little bit reasonable and to a great extent very unintelligently moved in quite unreasonable ways." ${ }_{18}$ "The truth is that men are moved by a variety of impulses whose nature has been determined through long ages of the evolutionary process without reference to the life of men in civilized societies." ${ }^{19}$

It is impossible to maintain successfully that there is a religious instinct. Nevertheless, man's

${ }^{17}$ William McDougall, Social Psychology.

${ }^{18}$ Ibid., p. II.

${ }^{19}$ Ibid., p. 10. 
religious beliefs rest, as a general rule, upon several instincts as their necessary support. Mr. McDougall analyzes the emotional components of the religious life $\mathrm{e}^{20}$ into three complex emotions: admiration, awe, and reverence. These complex emotions, in turn, he analyzes into simple emotions, each of which is associated with one of the primary instincts. Thus he says that admiration consists of wonder and negative self-feeling, awe consists of admiration and fear, and reverence consists of awe together with the tender emotion. The simple emotions, then, which in combination are at the basis of the religious life, are: wonder, negative self-feeling, fear, and the tender emotion. Each of these simple emotions coexists with one of the following primary instincts, in the order given: curiosity, self-abasement, flight, and the parental instinct. ${ }^{21}$ Even though we should not accept all the details of Mr. McDougall's rather too neat and well-ordered classification of the instincts and emotions, still we can not doubt the connection between emotions and instincts, and we can not doubt that these four instincts, and probably others, form an indispensable basis for religious belief. The possession of these instincts and emotions does not in itself constitute a man's

${ }^{20}$ Ibid., Ch. XIII.

"Ibid., Ch. III. 
religion. A man is not religious unless he also has a belief as to the reality of some more or less supernatural object or objects about which these instircts are united into a religious complex. But, without such instincts as driving forces in human life, religious belief would not exist among men.

Mr. McDougall's discussion of the instinctive basis of religion might be supplemented by a greater emphasis than what he places upon the instinct (or sentiment) of love ir the economy of the religious life. Freudian psychology explains religion as a sublimation of the sex instinct. Human love, when denied its normal human satisfaction, or else passing beyond such satisfaction, seeks and finds compensation in a religious world of the imagination (believed real, of course), a world the existence of which depends solely upon the creative power of human love. Perhaps the Freudian view seems crude and ultra-prosaic, but Freud has simply expressed in plain words what poets and philosophers have long recognized. Plato has described the truly religious love of eternal goodness and beauty as a growth out of ordinary human love. ${ }^{22}$ Emerson has expressed a similar thought in reverse form in saying, "Love . . is the deification of persons." ${ }^{23}$ And Browning, most em-

${ }^{22}$ See the Symposium.

${ }^{23}$ Essay, Love. 
phatically of all poets, makes human love and religion closely akin. It is a common observation that people often become religious under either one of the two following conditions. Those whose earthly love has been thwarted may turn to the religious life for its transcendent compensations. The classic case is that of the woman who withdraws from the world into a nunnery because of a disappointment in love. On the other hand, many who were not previously religious become so upon "falling in love." Then, as Emerson says, "Nature grows conscious," and the attitude of the lover towards the universe at large becomes truly religious. Even definite religious beliefs may now be adopted wholly as a result of love, which, in its origin and evolution, has been of such profound biological significance.

The instinctive basis of religious belief is simply illustrative of the biological basis of many of man's more spontaneous opinions and beliefs-the ones least subject to exact scientific verification or refutation. 'The conditions of man's age-long precivilized and even prehuman life, during which the primitive instincts arose and developed, probably as chance variations or mutations preserved by natural selection, or perhaps as racial habits becoming hereditary, account for the existence and permanence of many present-day beliefs. 
The further fact of the direct survival value of certain beliefs, which renders them permanent in human life, whatever may be the source from which they arise, has already been pointed out in other connections. Dr. Schiller's study of "Axioms as Postulates".24 is a striking illustration of a biological explanation of the rise and survival of principles that have come to seem self-evident and without need of historical origin. James has spoken of the categories of our common-sense ways of thinking as the discoveries of "prehistoric geniuses whose names the night of antiquity has covered up," and he has given a biological explanation of the survival of these categories. Dr. Schiller has recently pointed out that the acceptance of this life as real and not a dream, the rejection of solipsism, and the denial of pessimism, all rest upon biological foundations. ${ }^{25}$ In a similar manner I have discussed what I have called the ( I) hygienic, (2) moral, (3) industrial, (4) scientific, (5) artistic, (6) social, and (7) legal values of primitive religious beliefs, and the (I) hygienic and (2) moral values of religious beliefs in the higher religions. ${ }^{26}$ These values have all been of a fundamentally biological type.

${ }^{24}$ Loc. cit.

${ }^{25}$ "Truth and Survival Value," loc. cit.

See above, Ch. I. 


\section{III}

Though, in the matter of explaining the genesis and the present basis of significant beliefs, especially religious beliefs, I am in precise agreement with the biological treatment accorded to the problem by such pragmatists as James and Dr. Schiller, there arise, nevertheless, differences of view that appear so striking as to have caused Dr. Schiller to single me out ${ }^{27}$ as representing in my own errors two fallacies "to which all logic has habitually been addicted." 28 Both of these fallacies attributed to me, called the fallacy of ex post facto wisdom and the fallacy of confounding the persons, hive to do with the question of the relation b.tween truth and value, especially survival value. What I have called the pragmatic fallacy ${ }^{29}$ is involved in the argument. In my original definiticn of this fallacy I insisted that truth was a logical matter unrelated to the question of value, and that the pragmatic fallacy consisted of taking value, especially survival value, as a test of the truth of beliefs. Dr. Schiller, on the other hand, like James in the later developments of his rarmaric views, asserts that, even though truth ni' survival value are not identical, "it might be-

urnal of Philosophy, Psychology, and Scientific Methoa vol. XV, pp. 508-10.

a., p. 508 .

Sce àiove, Chs. II and III. 


\section{On Truth and Survival Value}

come necessary to equate [them] in principle." ${ }^{30}$

The whole question, in the last analysis, reduces largely, if not wholly, to a question of verbal usage-a question as to the application of the word "truth." I accept without reserve Dr. Schiller's account of the biological grounds of belief. I would agree that "it is even possible that ultimately and indirectly all [beliefs, though nut all 'truth-values'] are affected by the survival value test." ${ }^{31}$ But I would assert that one goes contrary to established usage of the term "truth" if one asserts that the truth of beliefs is tested by their survival value. In regard to the biological impossibility of pessimism as a permanent creed, I have expressed views, ${ }^{32}$ independently of Dr. Schiller's recent account of this matter, as I have already remarked, that agree precisely with Dr. Schiller's account. That is, I have maintained that it is biologically impossible that pessimistic beliefs should survive in the race, since, for biological reasons, a pessimistic race would soon perish from the earth. But, so far as pessimism is conditioned by some disillusioning naturalistic type of philosophy, scientists and philosophers might agree that such a philosophy is true even though its acceptance were psychologically and biologically impos-

${ }^{30}$ Loc. cit., p. 514 .

${ }^{31}$ Schiller, loc. cit., p. $5 \mathrm{I} 4$.

${ }^{82}$ American Journal of Psychology, Vol. XXIX, pp. 383-92. 
sible for any very considerable number of people. Common sense and science assert that "truth is so," whether or not it is known by any human mind. On the other hand, pragmatism of Dr. Schiller's type asserts that truth is personal and subject to psychological and biological conditions. I would myself try to mediate between these two contrary positions. I would say that common sense and science are correct so far as the meaning of the term "truth" is concerned, for, indeed, common sense and scientific usage together determine the meaning of any term. ${ }^{33}$ I would say also that pragmatism is correct so far as its account of the genesis and growth of beliefs in a fundamentally biological context is concerned. But even beliefs that are universally grounded in biological needs of human nature need not thereby be true. They are believed true, of course, for to hold a belief implies believing that the first belief is true; but beliefs which were universally held might fall to satisfy the scientific test of truth if sufficiently accurate methods of scientific verification were devised.

It was recognized by Aristotle that convention establishes the meaning and denotation of words; but philosophers, more than any other class of

\footnotetext{
${ }^{23}$ See the author's article. "Behaviorism and the Definition of Words," Monist, Vol. XXIX (1919), pp. 133-40.
} 
men, have persistently erred in insisting that a given word means this or that, without asking the simple, concrete question as to what, in actual human usage, the word does mean. We may illustrate the part that human usage plays in establishing the denotation and the meaning of words by referring to the original fixing of names to objects in the growth of language, speaking, for the sake of concreteness, in terms of an incident recorded in Hebrew mythology. When Adam confronted an animal kingdom of unnamed species, the cat became a cat when he called it a cat, and in like manner the dog became a dog. "Whatsoever Adam called every living creature, that was the name thereof." Adam did not create the animals, but he did create their names, together with the relations of reference that were involved. Adam did not judge that this animal was a cat, that, a dog, for there was no chance of his being in error. The names of the animals were a creation, not of Adam's judgments, but of his acts of postulations. That is, Adam created the symbols (the names of the animals) and arbitrarily determined what the symbols should denote. I have spoken figuratively; but for Adam substitute the whole human community, for the animal kingdom substitute the entire world of objects, and the situation is not altered except in the extent of application of the principles involved. 
The question of the meaning of "truth" becomes first of all the empirical task of asking just what, in popular and in scientific usage, the word is used to refer to. I submit that, in popular or commonsense usage, "truth" is thought to mean simply what is "so"; and in scientific usage it is taken as predicable of theories, hypotheses, propositions, and assertions that conform, in a definitely recognized scientific manner, to the facts of the situations in question. Furthermore, in both popular and scientific usage, the truth is taken to be entirely independent of what anyone may like to believe, or of what anyone may be led to believe for subjective reasons. In other words, truth is depersonalized in popular and in scientific usage; truth is a logical matter and not a psychological matter.

That the unsophisticated mind thinks of truth in such impersonal and immutable terms is illustrated by the first popular response to the pragmatic theory of truth when interpreted as offering an excuse for lying. ${ }^{34}$ Though pragmatism asserted that the valuable in thought and belief is the true, still the popular mind, more upright, perhaps, than the mind of the pragmatist after it had become all "sicklied o'er with the pale cast" of Protagorean sophistries, refused to give up its respect for

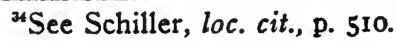


genuine truth. An austere respect for truth as something independent of all personal relations to it, is well expressed by the poet when he stoically asserts :

"It fortifies my soul to know

That, though I perish, truth is so."

The scientific ideal of depersonalized truth is well expressed in the passage quoted above from Mr. Russell. Scientists endeavor to establish laws and theories which the objective facts, and the facts alone, will substantiate. Sciences succeed so far as they become mathematical and experimental. Personal relations of the experimenter to the processes which he is studying are not allowed to prejudice conclusions or to decide issues if it is possible to avoid such vicious influences.

One of the chief differences between the pragmatic usage of "truth" and the scientific usage of the term is presented in the example, cited by James, of the Ptolemaic versus the Copernican theory in astronomy. Pragmatism claims that truth is personal, and fundamentally an attribute or predicate of beliefs as psychological processes. What is believed to be true, and proves serviceable for definite reasons, is declared by the pragmatist to be true. Therefore the pragmatist asserts that the Ptolemaic theory was actually true so long as it was believed true, since the belief 
proved serviceable in various ways. On the other hand, those not pragmatists would say that the Ptolemaic theory never was true, since it never accurately represented the facts of the case, as has since been proved. Scientists would assert, further, only that the Copernican theory is probably true. It seems to represent the facts accurately. But, they will say, whether it is really true or not depends, not upon the mere serviceability of the belief, but upon its conformity to the facts. Perhaps, scientists would admit, no theory can ever be shown absolutely to be true, since the establishing of its truth is a human and therefore an imperfect process. Scientists will insist, however, that the truth of a theory, if it could be known abso. lutely, would be found to depend entirely upon its impersonal relations to objective facts.

Though the later developments of James's pragmatism largely obliterated the distinction between truth and value, especially survival value, James had the scientific theory of truth still in mind in his earlier works. ${ }^{35}$ Thus, according to the earlier views of James's, though naturalism might be the true philosophy, in the sense of being the one that describes the facts of the universe correctly, idealistic and theistic beliefs would probably persist permanently in the minds of men

${ }^{3}$ See The Will to Believe, p. II6. 
because man's emotional needs determine so largely what he believes. The pragmatist would here assert that theism is true because the belief persists and "works"; but those with a non-pragmatic theory of truth would still maintain that, in the universe of discourse in question, naturalism would be true, even though theistic beliefs persisted and were valuable, biologically and otherwise.

In his controversy with Professor Perry, not so very long ago, ${ }^{36} \mathrm{Dr}$. Schiller described the pragmatic theory of the meaning of truth by means of a concrete illustration. Speaking of the World War, Dr. Schiller said: "What would happen if the victors prevailed so utterly as to establish their version of the truth? Would not the divergent accounts be voted down as false? According to Professor Perry some of these deserve to be called truer, but is it not amazing that he should regard the situation as not in the least derogating from 'the theoretic truth' of the beliefs that are rejected." ${ }^{37}$

On the contrary, it seems to most of us, I think I may safely say, that it would be more amazing if military victories should always be on the side of the truth. "Divergent accounts would be voted

${ }^{20}$ Cf. Mind, N. S., Vol. XXIII (1914), pp. 386-95; Vol. XXIV (1915), pp. 240-49; pp. 516-24.

"Mind, N. S., Vol. XXIV, p. 522. 
down as false," because they would be voted down by the victors, but is the cause that lacks military support necessarily false? Germany might conceivably have prevailed over the Allies, but would Dr. Schiller ever have accepted as true the views for which Germany has stood? We are easily led to think that right and truth have always been on the winning side throughout military history, but one reason for thinking so may be the fact that those groups which have been victors by force of arms have been the survivors and consequently the final judges of the right and truth of the issues involved. The biological struggle for existence is the most fundamental factor in determining what social, political, and religious beliefs shall survive and be held as true, but it does not give assurance of the truth of these beliefs.

So long as one maintains the distinction which I have made between beliefs and disbeliefs as properly to be regarded as positive and negative responses to propositions, the propositions being non-psychological, and true or false according to their relations to facts external to them, there can be no possibility of committing the pragmatic fallacy. By courtesy, as I have said, we may speak of true and false beliefs and judgments; but fundamentally truth is a logical matter in which only propositions, the- 
ories, hypotheses, etc., are involved, while the finding of these propositions, or the attempt to find them, and to verify them, is wholly a psychological matter, of which truth and falsity may not properly be predicated. This distinction between logical and non-logical matters, between propositions and beliefs, allows for a clear-cut distinction between the value of beliefs subjectively considered, and the truth of propositions objectively considered; and it conforms both to popular and to scientific usage of the word "truth."

Furthermore, so far as this distinction is made, the two fallacies which Dr. Schiller ascribes to me are not found in my statements. The fallacy of ex post facto wisdom, relating to "wisdom after the event," as, for example, in the case of the Ptolemaic and Copernican theories, is clearly nc fallacy in the reasoning of one who separates the earlier belief in the Ptolemaic theory from the non-psychological aspects of the theory, and who separates the present belief in the Copernican theory from its logical aspects, and simply contends that the Ptolemaic theory was false, even though believed, just as the Copernican theory might now be false, even though believed. I have simply asserted that some false beliefs have had valuable subjective effects, in the case, for example, of religious beliefs in the course of human 


\section{The Biological Foundations of Belief}

evolution; and in asserting this I have committed no fallacy of ex post facto wisdom.

The fallacy of confounding the persons, again, can be asserted only of those who predicate truth and falsity of psychological processes. Both popular and scientific usage, to which I have tried to conform so far as the meaning of the term "truth" is concerned, depersonalize truth; and usage of the terms as well as the facts of the situation allow one to assert of belief that a false belief, that is, an acceptance of a false proposition, may sometimes have value in case the believer is unaware of his error, because of the subjective effect of the belief upon the believer. For example, the belief in God might contribute to a man's happiness and morality, even though there were no God.

Finally, the pragmatic fallacy is still a genuine fallacy, committed by those who maintain that the emotional effect of a belief upon an individual, or the biological effect of a belief upon a race, is a criterion of the truth of the proposition believed. I agree with the pragmatic description of the biological grounds of belief, but I contend that beliefs need not always be true in order to be valuable. To say that beliefs, because valuable, can not be errors or delusions, but must be true, is to commit the pragmatic fallacy. 


\section{CHAPTER V}

RELIGIOUS AND MORAL EDUCATION ${ }^{1}$

7 HERE is no such thing as a modern infant. 1 The modern individual begins his career at precisely the same point at which each cave-man started. Only in the world of mythology does an individual spring forth, like Minerva, full-fledged in wisdom. In the actual world a long period of infancy, childhood, and youth must precede intellectual and moral, as well as physical, maturity. Present-day studies in genetic psychology have begun to reveal the real needs of the child, needs that are not at all the needs of the adult. Just as the infant's physical food is not that of the adult, so the intellectual, moral, and religious pabulum of the child is not properly that of the mature individual. Psychology gives us a scientific basis for requiring the child to speak, understand, and think as a child, while expecting the man to put away childish things. Especially in the field of religious and moral education is it imperative to take into account the needs of childhood and youth, and it

${ }^{1}$ This chapter is a combination of two articles published in the American Journal of Psychology, Vol. XXVIII (1917), pp. 504-507; and Vol. XXIX (1918), pp. 371-82.

93 


\section{The Biological Foundations of Belief}

is precisely these early religious needs that have been persistently ignored. As President Hall says," "From the old New England Catechism to President Eliot's latest pronouncements reducing religion to ethical culture, American educators have to an extraordinary degree ignored the nature and the higher needs of the child, and persistently assumed that whatever was good for them was, of course, good for him."

My purpose in discussing the value of religious beliefs in individual development, beliefs of different kinds for different stages of development, is to combat two tendencies in present-day practice. One modern tendency is to give the child and youth absolutely no religious instruction. Many parents who have no religious beliefs themselves oppose the teaching of religion to their children on the ground of its untruth. If, as Professor Leuba has shown, ${ }^{3}$ the majority of scientists do not believe in even the most essential of religious objects, God and immortality, it is probable that many of them would oppose the teaching of religion to children for the reason that, as they think, religious beliefs are false. Against such a view I would urge the teaching of religion for reasons of its value, regardless of its truth. Another class, the

${ }^{2}$ G. Stanley Hall, Educational Problems, Vol. I, p. 146.

J. H. Leuba, The Belief in God and Immortality. 
class of religious believers, would, in many instances, teach children the very same religious views that they think fit and proper for adults; and I would urge against this tendency the fact that the religious needs of the child are not the same as the religious needs of the adult.

\section{I}

The correct view-point from which to study the problem of religious and moral education is best furnished by the theory of recapitulation. This essentially biological theory, when expanded into a psychological theory, is important in giving a proper genetic attitude towards instruction in religion and morals.

The similarity between early human embryonic stages and lower forms of life was observed by embryologists early in the nineteenth century, and the theory of recapitulation was first clearly stated in its full evolutionary context by Fritz Müller in I 863 , and then by Haeckel, under the name of "the fundamental law of biogenesis." Haeckel's statement of the law is as follows:" "The rapid and brief ontogeny [the life history of the individual] is a condensed synopsis of the long and slow history of the stem (phylogeny): this syn-

\footnotetext{
'Ernst Haeckel (Joseph McCabe, translator), The Evolution of Man, Vol. II, p. 357.
} 


\section{The Biological Foundations of Belief}

opsis is the more faithful and complete in proportion as palingenesis [the reappearance or repetition of old, ancestral traits] has been preserved by heredity, and cenogenesis [deviation from the phylogeny of the group] has not been introduced by adaptation." This statement includes both the general law and its limitations. Each individual in its development repeats its ancestral history, but not precisely. Many ancestral traits are lost, new traits appear, and there are numerous shortcuts.

Though it is not maintained by any biologists that the individual in all the details of its development climbs up the ancestral tree, still the theory in its broad outlines is accepted by practically all biologists. That this is true is shown by the fact that the theory is incorporated in the standard textbooks of biology and zoology. Human development, viewed in the light of this theory, is seen to be through stages represented ancestrally by the protozoa, by a radially symmetrical stage, by bilaterally symmetrical forms of life, $i$. e., by fish, by amphibia, and by simian forms, before the individual becomes relatively human at about the end of the second year. Such facts, unquestioned by biologists, are so significant that anthropologists and psychologists have carried the law of biogenesis further, to cover mental development 
through childhood and youth. There is not so clear a case for mental recapitulation, yet it is denied by few, and it is explicitly accepted by many. Thorndike $e^{5}$ is one who denies the applicability of the biogenetic law to human development, but his arguments against it are very inconclusive. $\mathrm{He}$ does little more than point out limitations of the theory, and everybody admits that the theory has limitations. Thorndike himself, however, accepts the theory in some cases. ${ }^{6}$ Baldwin $^{7}$ and Hall ${ }^{8}$ are among the most conspicuous psychologists who accept and employ the doctrine. President Hall perhaps carries it to somewhat extreme limits in many cases, and yet his application of it to religious education is of inestimable value. McDougall ${ }^{9}$ also accepts the theory, as does Freud. ${ }^{10}$ Professor $\mathrm{Coe}^{11}$ employs the theory in his discussion of religious and moral education.

\footnotetext{
'See E. L. Thorndike, Educational Psychology, Vol. I, The Original Nature of Man, Ch. XVI.

OP. cit., Vol. II, p. 99.

'J. M. Baldwin, Mental Development in the Child and the Race; Social and Ethical Interpretations; $A$ Genetic Theory of Reality.

${ }^{8} \mathrm{G}$. Stanley Hall, Adolescence, 2 vols.; Educational Problems, 2 vols.; and other works. 180.

${ }^{3} \mathrm{Wm}$. McDougall, Psychology, the Study of Behaviour, p.

${ }^{10}$ See especially Sigmund Freud (A. A. Brill, translator), Totem and Taboo, New York, $19 \mathrm{r} 8$.

${ }^{11} \mathrm{G}$. A. Coe, Education in Religion and Morals. See especially pp. 2ri-25. Mr. Cephas Guillet ("Recapitulation and Education," Pedagogical Seminary, Vol. VII, pp. 397445) has made an extensive survey of the theory in its general application to education.
} 
If not carried out in too extreme detail, the theory of recapitulation is of at least some service in explaining child development. As McDougall says in the reference given above, "The study of children . . . has been rendered far more fruitful of results than it otherwise could have been by the light thrown by the theory of organic evolution and by the principle of recapitulation." In the first two or three years of life, the foetal stage included, the individual recapitulates the prehuman stages of evolution. Phylogenetically, prehuman stages represent an evolutionary period many times greater than the period during which man has existed. Yet we observe that the individual spends a much longer time recapitulating human than prehuman stages. This, however, is in accordance with the general operation of the biogenetic law. The oldest forms of racial life are recapitulated most rapidly, and the more recent ancestral forms, more slowly. The length of time taken to recapitulate a period does not depend upon the phylogenetic duration of the period so much as upon its recency in the ancestral series. It is to be expected, consequently, that the recapitulation of the human racial stage, representing perhaps a duration of a million years, should take a much longer time than the recapitulation of all the prehuman phylogeny, though this represents a period of many million years. 
President Hall divides the stages of individual development into four periods, which he calls those of infancy, childhood, youth, and adolescence. The stage of infancy, lasting until the end of the second year, which has been called the simian stage, does not concern us now, nor does the fourth stage, of adolescence, occurring from the age of about thirteen to twenty-five or thirty, except the first few years of its beginning, for recapitulation does not occur after the beginning of adolescence. It is the stage of childhood, from two to eight, and that of youth, perhaps better called that of later childhood, lasting from eight to twelve or thirteen, that are of greatest importance for our immediate study. The age of childhood, with its imaginative activities, represents the savage stage, marked by a close relation to nature and a tendency to personify physical objects and to confuse the animate and the inanimate. The period of youth represents racially, according to President Hall, the culmination of a long line of savage development -a long and relatively stationary period in racial history. This is the age preeminently of physical activity and practical adjustment. In adolescence the stage of later civilization in the race gains ascendency in the individual, and here the emotions tend to predominate.

The plan of education on a recapitulatory basis 
is to furnish to the developing individual, as far as this is possible, the appropriate environment for his stage of development. In religious education this means encouraging the natural succession of religious beliefs, just as they have occurred in the history of the race.

Religions may be divided historically into nature and redemptive religions. The chief distinctions between the nature and the redemptive religions may be expressed in terms of the difference between human desires for satisfactions of a temporal and earthly sort, and desires for transcend. ent satisfactions. The earliest, preanimistic type of religion, a later type dominated by a generally animistic philosophy, both types belonging to the tribal stage, and the national, and more or less legalistic religions, such as are best illustrated by early Judaism, would all be included under nature religions. Early Judaism is a nature religion for in early Judaism Jehovah existed for the affirmation of "this world." Such religions as Zoroastrianism, Mohammedanism, Brahamanism, Buddhism, Judaism in its later development, and Christianity, are called redemptive religions. There is a clear and recognizable distinction between those religions in which gods are invoked to satisfy man's desires for material prosperity, and other religions that offer satisfaction to man's desire for "the peace that passeth understanding." 
It is possible, I said, to distinguish two classes within the nature religions, that is, the primitive and the morality religions. The morality religions, best exemplified by early Judaism, are still nature religions, but they have advanced beyond the stage of the primitive religions, because of the development and moralizing of the gods, and especially through the rise of some form of monotheism. There is a moral element in the primitive religions, $e . g$. , in taboo, but such a moral sanction is clearly on a lower plane than the morality of the Mosaic code. Thus we may arrive at a three-fold classification of historical religions, like Sie. beck's, ${ }^{12}$ including ( I ) primitive, (2) morality, and (3) redemptive religions. Such a classification is best for furnishing a background for the recapitulation theory.

Roughly corresponding to the three stages of religious evolution in the race, there may be distinguished three stages of individual development. Childhood and the early part of what President Hall calls youth correspond to the stage of the primitive religions. The period of youth, especially the later part, corresponds to the stage of the morality religions. The beginning of adolescence marks the rise of the redemptive religions

\footnotetext{
${ }^{12}$ See Hermann Siebeck, Lehrbuch der Religionsphilosophie, pp. 52-16r.
} 
IO2 The Biological Foundations of Belief

in the race. Such a correspondence, obviously, holds only in a general way. There are wide variations from it, for individual differences are great. It is an ideal correlation, which is never realized completely, but there is value in trying to approximate it.

Childhood and youth, according to the theory of recapitulation, are stages of external authority, for they correspond to times in racial history when the individual was wholly subject to taboo, to the "folk-ways," and to priestly control. During adolescence moral sanctions should lose their external character. Beliefs in taboos have their place in childhood, because of their moral influence; and in youth belief in a God of law, whose commands are right because commanded, likewise possesses positive moral value. A recapitulatory scheme of rcligious and moral education furnishes a basis for discipline in the early stages of development. Out of the imaginative nature worship of the child there should be allowed to grow a conception of a God who is the author of inviolable law. Belief in a stern God of law should only gradually give place to belief in a God of love at the time of the emotional awakening at the beginning of adolescence. However impracticable the theory may seem, since such discipline is implied by it, it has actually been prac- 
ticed, deliberately or unconsciously, more extensively than is commonly supposed.

The early belief in taboos, and, growing out of this, the belief in God-given codes of law, are instrumental to the maintenance of desirable forms of conduct during early life, and to the formation of good habits that will persist after the disciplinary beliefs that once supported them have disappeared. As it was with the race, so it should be with the individual. Moral education should begin with taboo, and belief in a God of external authority is the strongest support of morality at the dawn of adolescence. As Partridge says, summarizing President Hall's view: "The widespread view that morality can be taught without religion is wrong. . . Children must have a sense of God as giver of laws, whose demand is right because $\mathrm{He}$ wills it; and certainly at adolescence there must be religion to guide the moral life, if at no other time."13

The maintenance of a legalistic stage in the religious development of children may seem at first thought like the imposition of undue rigor and sternness, approaching ascetic discipline. A certain degree of asceticism, however, is defensible, and necessary for the sake of future gain. The universe does not grant immediate satisfaction to

${ }^{18}$ G. E. Partridge, Genetic Philosophy of Education, p. 185. 
104 The Biological Foundations of Belief

all of man's desires, and the habit of accepting with calmness the evil with the good should be established early. An element of Stoicism is needed in every stable character, and the discipline of early religious beliefs is valuable as a means to the attainment of such a character. James inquires: ${ }^{14}$ "Does not . . the worship of material luxury and wealth, which constitutes so large a portion of the 'spirit' of our age, make somewhat for effeminacy and unmanliness? Is not the exclusively sympathetic and facetious way in which most children are brought up today-so different from the education of a hundred years ago, especially in evangelical circles-in danger, in spite of its many advantages, of developing a certain trashiness of fibre? Are there not hereabouts some points of application for a renovated and revised ascetic discipline?"

The question of moral discipline divides American educational theorists into two camps. Professor Dewey represents one tendency, which is, in general, opposed to discipline. President Hall and his followers represent another tendency, which lays emphasis upon moral discipline. The truth probably lies somewhere between these divergent views.

${ }^{24}$ William James, The Varieties of Religious Experience, p. 365 . 
It is claimed by Dewey and his followers that democracy and discipline are contradictory. Discipline is supposed to go along only with an autocratic and militaristic form of society. The leading aim of American education, good citizenship in a democracy, if it is to be achieved through the operation of the principle of learning by doing, requires, it is claimed, that children, the citizens of tomorrow, shall learn the democratic principles of self-government by governing themselves today. President Hall accepts the theory of recapitulation as the basis of his view that a certain amount of discipline is necessary in the moral training of children. Such a view maintains equally with Dewey's that democratic citizenship is an important educational aim, perhaps the one most comprehensive aim in American education. It would point out, however, that democracy is the latest stage in racial evolution, a stage which is still in process of becoming established, and that individuals in the immaturity of their childhood and youth ought to relive the earlier life of the race, with its priestly control and its external constraints, before being fitted to take up the duties belonging to the highest stage of racial development.

Recognizing that the theory of recapitulation implies moral descipline, Dewey no longer ac- 


\section{The Biological Foundations of Belief}

cepts it, ${ }^{15}$ though he did so earlier. ${ }^{16}$ As a matter of fact, an acceptance of the theory, with its implied discipline, does not contradict democratic principles; it simply prescribes a postponement of their application in the nurture of children.

\section{II}

The questions of discipline and of the value of taboo and of beliefs in legalistic religions are questions that merit consideration by themselves. Freudian psychology may be able to contribute something towards a solution of the problem.

There is among educational theorists and others at the present time a somewhat general tendency to rule out discipline, in favor of methods that will allow free self-expression, with trial and error as the first of the ways whereby the child is to learn what is right and wrong. Thus Professor $\mathrm{Holt}^{27}$ argues against taboos for children. $\mathrm{He}$ contends that unless the child is allowed to follow up his impulses to their conclusions, and to learn avoiding reactions in the case of undesirable and dangerous objects through experience with the objects themselves, the proper integration of reflexes will not occur to make later conduct reliable. This is all true within limits: but in many cases the bad

\footnotetext{
${ }^{25}$ Democracy and Education, 1916, pp. 84-89.

${ }^{20} T$ he School and Society, 1899, p. 62.

${ }^{27} \mathrm{E}$. B. Holt, The Freudian Wish, Chs. III, IV.
} 
consequences of an act are so long deferred that the child will never associate the consequences with the cause; or the consequences may in some cases be immediately disastrous, or perhaps fatal. In such cases the child learns nothing from the experiences, or else learns at too great a cost.

Professor Holt's argument against taboo is inadequate for it is based upon an inadequate conception of taboo. His example of taboo is not an instance of taboo at all. He argues that, in the case of the child who is forbidden by the mother to touch the flame, the child's behavior becomes a function, ${ }^{18}$ not of the flame alone, but of the situation-the flame plus the mother. From this it follows, Professor Holt says, that in the absence of the mother, who is the source of the taboo, the child will burn himself in the flame. But this is not a case of taboo at all. Taboo involves belief in some superhuman, invisible intervention in the event of doing a forbidden act. So, in the case of genuine taboo, there is no harm caused by behavior becoming a function of the object plus the taboo-character of the object. The source of the taboo is always present, and safe conduct is thereby assured. In later life the belief in many, perhaps all, earlier taboos will disappear, but proper

${ }^{18}$ See Professor Holt's definition of behavior, op. cit., Supplement, "Response and Cognition," pp. 153-208. 
ronduct will continue in most instances for two reasons: first, because the correct habits that have been formed under the influence of taboo will tend to persist and to act just as mechanically as original instincts; and, second, because, for the more mature individual, new and adequate rational sanctions for the continuance of the acquired type of conduct arise and take the place of the original taboos. No harm results even if all taboos do not disappear, for, as James says, "The highest form of character, . . . abstractly considered, must be full of scruples and inhibitions." 19

The two most fundamental instincts, from which the other instincts have developed, are the food-getting and the sex instincts. The regulation of the sex instinct is one of the constant problems confronting society. I would contend that, just as all education in sex morality ${ }^{20}$ in the race began in taboo, so sex taboo of some sort is necessary for the maintenance of desirable standards of conduct during the formative stages of individual development. Münsterberg ${ }^{21}$ argued for a certain amount of taboo in sex education. McDougall ${ }^{22}$ advises against too great a rationalization of the sex problem in early education. And Freud recognizes the

${ }^{19}$ Talks to Teachers, p. 179.

${ }^{20}$ See Ernest Crawley, The Mystic Rose.

${ }^{2}$ See Psychology and Social Sanity, pp. 17-19; 59-61.

${ }^{22}$ Social Psychology, 8th edition, pp. 419-2I. 
necessity of inhibitions for physical and moral reasons, as a part of the sublimation process.

Freud insists upon the necessity of early sub. limation of sex energy into socially useful chan. nels; and sublimation, though positive, requires as its correlate a negative factor to check the primary expressions of sex in children. A recapitulatory theory of religious education provides both the negative factor, some sort of taboo or religious interdiction, and also the positive conditions that favor sublimation through supplying the growing individual with an environment suited to call out such activities as are socially acceptable and also in accord with the developing interests of the individual. Harm would result if the primitive desires and activities of children were forbidden, and if at the same time no new positive interests were encouraged; but, along with the encouragement of new, socially desirable activities, undesirable tendencies must be discouraged.

On Freudian principles religion is a valuable form of sublimation, especially at the beginning of adolescence, as well as earlier. Freud says: "Owing to the oppositional relation existing be. tween culture and the free development of sexuality, the results of which may be traced far into the formation of our life, the problem how the sexual life of the child evolves is ... of very 


\section{The Biological Foundations of Belief}

great importance in the higher stages of culture and civilization." ${ }^{23}$ Sublimation is the process by which sexual energy is utilized in other, non-sexual spheres, and in directions which are more approved of by society, and which are ultimately of more value for the individual as well as for society. Art and religion are the chief forms in which sublimated sex energy expresses itself.

According to Freud, the child has numerous perversions in his sexual predispositions. That is, in his earliest years he has tendencies towards homo-sexuality, exhibitionism, sadism, masochism, etc. It is through sublimation of these perverse tendencies that normal sexuality and a moral character are developed. The "sexual latency period," from about the fourth year to the beginning of puberty, is the time when repression of perverse tendencies, and sublimation, are necessary. Inhibition of the early tendencies is necessary if neurotic disturbances are to be avoided in later life. Both normal and neurotic adults possess repressions in some degree. In neurotic individuals the repressions are not complete, and they consequently manifest themselves as symptoms of the neuroses, while in normal, healthy individuals repressed wishes are inert, or else they

"Sigmund Freud, Three Contributions to Sexual Theory (A. A. Brill, translator), p. 85 . 
manifest themselves only in dreams. Repression alone, without sublimation, or substitution, will always have bad results; but Freud and most Freudians recognize the necessity of social and religious restraints, inhibitions, and taboos, as a part of the normal sublimation process. Thus Brill says :

"Were it not for the severe checking the individual constantly experiences from the very beginning of his childhood, which causes him to give up most of his desires, it would be impossible to live in any society, savage or enlightened. . .

"This inhibiting process begins in childhood and is continued throughout life. . . . Throughout the whole course of our existence, society (religion and ethics) teaches us to curb our desires and to give up what we want. We want much and we get comparatively little, but we never stop wanting." 24

"Civilization, so called, simply consists of inhibitions imposed upon the individual by religion and society. The more one can inhibit his primitive impulses the more cultured he is, and savages and children must be taught inhibition to fit them for society."25

There is no virtue, of course, in curbing desires

${ }^{2} A$ A. A. Brill, Psychanalysis, pp. 40, 4I.

"Ibid., p. 263. 
except for the sake of greater satisfactions; and it is for precisely this result that many of the desires of early childhood should be repressed and sublimated. Later health, not only moral, but also physical, requires sublimation, according to Freud. Whether the activities of the child shall develop into socially acceptable forms, depends upon the success that attends sublimation. Later neuroses result from unsuccessful sublimation and repression.

Freud's psychology has a distinct recapitulatory background. This is shown especially in his book, Totem and Taboo, as is suggested by the sub-title. "Resemblances between the Psychic Lives of Savages and Neurotics." Since the adult neurotic individual represents a continuation of, or reversion to, psychic infantilism in the sexual life, the normal child, like the neurotic adult, is on a mental plane corresponding to that of the savage. What is normal for the savage and for the child, is a symptom of disease in the civilized adult.

Freud probably overemphasizes the rôle of the sex instinct in the economy of life, both in healthy and in diseased conditions. Such is the opinion of many critics. But critics such as $\mathrm{McD}$ ougall, ${ }^{28}$ while rejecting Freud's extreme emphasis upon the centrality of sex, are glad to accept his notion

${ }^{20}$ Op. cit., Supplementary Ch., II, "The Sex Instinct." 
of sublimation. Suppression of the primary forms of sex expression, and sublimation of sex energy into more desirable channels under the guidance of religious belief, have definite results of great value, as $\mathrm{McD}$ ougall points out. ${ }^{27}$

Much of the sublimation in later childhood would, in an ideal scheme of things, take place under the influence of religion of the legalistic sort. Then at adolescence sublimation would result, as it actually does in numerous cases, in a development into a new stage of religion, the stage of the redemptive religions. As $\mathrm{McD}$ Dougall says, ${ }^{28}$ "The intensification of thought and feeling [due to sublimation] may affect principally the religious interests, and then becomes a main condition of the conversion which is so characteristic of adolescence." So it is seen how religious beliefs corresponding to beliefs of the legalistic stage in racial evolution have positive value at the beginning of adolescence in guiding the moral life and in causing continued sublimation and a normal growth into the redemptive stage of religion. In the words of President Hall: "Adolescence . . . is a period when, whatever may be the truth about it, it is a wholesome pedagogical method to apply a

"Ibid., p. 424 .

${ }^{23}$ Ibid., p. 424. 


\section{4 The Biological Foundations of Belief}

transcendental, supernatural cult." ${ }_{29}$ "Religion, which has been the chief agent in regulating it [sex] in the past, must be also looked to in the future." 30

During early adolescence religious belief has a pronounced moralizing influence from the fact that the attribution of the new experiences, which are more or less inevitable at this time, to "higher" sources lends a seriousness and even sacredness to the experiences and to life as a whole. The individual who, with truer scientific insight, perhaps, attributes his new experiences of early adolescence wholly to physiological processes, possessing no religious significance at all, fails to get the inspiration of high moral ideals that are so valuable at this stage of development. The new emotions may be interpreted grandly or meanly, from "above" or from "below," idealistically or physiologically. For those experiencing the emotions there is value in the idealistic and religious way of interpreting the experiences.

\section{III}

Directly continuous with the problem of religious and moral education is the problem of in-

${ }^{39 * " C o l l e g e ~ P h i l o s o p h y, " ~ T h e ~ F o r u m, ~ V o l . ~ X X I X ~(1900), ~ p . ~}$ 412.

${ }^{30}$ Educational Problems, Vol. I, p. 460. 
struction in philosophy. The teacher of philosophy tends to be so exclusively a system-builder, with an eye single to the logical construction of his philosophy, that the concrete, human needs of his students are apt to be lost sight of. In general educational theory there is taking place a reform of method, and a reaction against the mere teaching of subject-matter regardless of the interests, aptitudes, and needs of the pupils. Teachers formerly taught subjects of study; now they teach children. The lesson learned from the elementary schools, that teaching should be ordered primarily to fit the psychological needs of the pupils rather than the logical claims of the subject-matter, may with profit be extended to the teaching of philosophy to college undergraduates.

The vast majority of individuals never become students of metaphysics in any technical sense of the term. Of those who study philosophy in college, many simply "take courses," for sundry reasons, without ever acquiring much interest in the subject. With a large number of the students who really become interested in philosophy, religious doubt is the beginning of a philosophical interest that arises in the attempt to bolster up a waning faith. Metaphysical interests arise in others as a direct outgrowth of the developing sex life in early adolescence, as in the case of Don Juan, who 


\section{6 The Biological Foundations of Belief}

"Did the best he could

With things not very subject to control,

And turned, without perceiving his condition,

Like Coleridge, into a metaphysician.

"He thought about himself, and the whole earth, Of man the wonderful, and of the stars, And how the deuce they ever could have birth."

As the poet says, with true Freudian insight, "puberty assisted" in bringing about Don Juan's philosophical interests.

Mere intellectual curiosity, or the pure love of wisdom for its own sake, is a possible though negligible cause of a student's interest in philosophy, at least at the beginning of his studies. As a general rule, philosophy is valued at first only as an aid in solving the fundamental problems of life, and not as an end in itself. With prolonged study, perhaps unfortunately, philosophy may become an end in itself, divorced from all practical problems of life, through a psychological process like that involved in the case of the man who took his first drink to save his life, and thereafter lived to drink.

"Longings sublime and aspirations high" come naturally enough during adolescence, and the instruction of college undergraduates should have due regard for the moral needs of the students. College students of philosophy desire little phil-

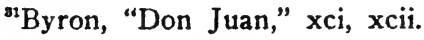


osophic dogmatizing from instructors, but, on the contrary, a free field in which to draw their own conclusions. The trend of their speculations can be guided, however, if instruction is insinuated gently, and not applied bluntly. Since metaphysics is a subject on which the most learned of doctors disagree violently, disciples are free, to a large extent, to choose metaphysical conclusions, such, at least, as are really relevant to human concerns, upon the basis of value, regardless of truth. The question thus presents itself as to the sort of philosophic beliefs that are most valuable for students. This problem is similar to the problem of the value of religious belief.

Whatever may be the latest philosophic conclusions of a teacher of metaphysics, they are usually not the same as his earliest conclusions. The failure of a man's metaphysical views to broaden and grow with continued study would be an indication of intellectual stagnation. In every special science, at least some few results are established, and accepted by all scientists without question. Such results have become fixed in the standard text-books. But metaphysics is a different matter. There is no generally accepted text-book of metaphysics. When it is the case that the teacher of philosophy has come to have somewhat different philosophic views from the ones that he held when 


\section{8 The Biological Foundations of Belief}

he was a younger student, as is the normal case, he is very likely to infer from this, if his attention is called to the matter, that his own students will not at first acquire philosophic truths in final form. Even if there be final and absolute Truth in metaphysics, the human acquisition of this Truth is a psychological process, always incomplete and always imperfect. The teacher of philosophy, as a teacher, should be primarily concerned, not with absolute Truth, but with the psychological learning processes of his students in their acceptance of some views and rejection of others, for emotional as well as for logical reasons. The student believes that his conclusions are reached by purely intellectual processes, but the educational psychologist recognizes that the passional nature is a large factor in the process.

Since human nature is such as it is, idealistic systems of philosophy, whether true or not, will always appeal to students of philosophy, and will be accepted by many for the reason that man's emotional nature, in so many cases, requires some sort of idealistic beliefs about reality. As James says, man's "will to believe" will assert itself in a large percentage of cases, and will accept an idealistic view of things because such a view is congruent with certain vital needs. Whether or not many of the current systems of philosophy 
that are called idealistic really offer support to man's specific religious beliefs, even the most fundamental of them, is a question that need not be raised. They at least seem to most students to do so, to offer a refuge of respectable supernaturalism against the encroachments of scientific naturalism. Upon the basis of value, and regardless of objective truth, the teaching of the great historical systems of idealism is certainly justifiable. $^{32}$ To force upon students a completely naturalistic philosophy, even if such were the true philosophy, a philosophy that proclaims the universe to be essentially indifferent to the ideals of man, would be extremely disintegrating, especially for those adolescents who were glowing with the enthusiasm of new moral aspirations. Naturalistic beliefs would crush out the incentive to noble effort. But belief in idealistic philosophies, with their appearance of devoutness, however vague, lends grandeur to the universe, and zest to the moral urgings of the individual life. Several men of my acquaintance, recent graduate students in philosophy and in other departments at Harvard, have told me that, while not now calling themselves metaphysical idealists, they nevertheless gained moral support and stability of character through studying, when undergraduates, such

${ }^{2}$ See G. Stanley Hall, Adolescence, Vol. II, p. 551. 
sympathetic treatments of idealism in its modern historical forms as are found in some of the chapters of Royce's Spirit of Modern Philosophy. This is, I think, a not uncommon experience. It is reported ${ }^{33}$ that Jowett encouraged the study of the philosophy of T. H. Green by Balliol undergraduates because of its religious value for the students who were in search of a substitute for their earlier religious beliefs.

Moral idealism is theoretically independent of any particular religion or system of metaphysics. It can be established to the full satisfaction of the intellect along with a naturalistic metaphysic as well as with an idealistic one. But practically, for actual human beings, most of whom, fortunately, are very incompletely intellectualized and de-emotionalized, theoretical moral idealism can become embodied in actual conduct only through the instrumentality of religious and idealistic beliefs. Belief in God and immortality, for example, tends to moralize the whole life, and to support such forms of conduct as are judged by the theorist to be right. The ethical theorist is concerned with discovering what is right. The preacher is concerned with influencing the will of man to do the right, that is, with making man's conduct conform to the standards set up by the theorist. Similarly

${ }^{23}$ See F. C. S. Schiller, Studies in Humanism, pp. 278-8r. 
the teacher of philosophy has a mission to perform in offering to youthful students such philosophic beliefs as will encourage, not discourage, moral effort on their part. 



\section{INDEX}

Aristotle, 84

Baldwin, J. M., 97.

Belief, behavioristic account of, 53-54, 7Iff.

Physiological effects of, 3 , 7-8.

See "religious belief."

Beliefs of scientists, 3,94 .

Biological grounds of belief, $74,76 f f$.

Biological value of religious belief, Iff, I4, 74ff.

Birth-rate and religious belief, $21 f f$.

Booth, M., 25-26.

Brightman, F. S., 42, 44ff, 64-65.

Brill, A. A., I11.

Browning, I8-19, 79-80.

Byron, I I5-I6.

Caird, Edward, 9.

Calvinism, 58.

Carver, T. N., 4-5.

Classification of religious values, $49 f f$.

Coe, G. A., 40, 4I, 97.

Coulanges, Fustel de, 2I-22.

Darwinism and pragmatism, $69 f$.

And religious truth, 43.

Dewey, J., 72, 105-06.

Discipline, moral and religious, I02ff.

Education, and democracy, 105. Religious, 93ff.

Recapitulatory theory of religious, 95ff, 102ff, 109.
Ehrenfels, C. von, 43.

Emerson, 79-80.

Fallacy of false attribution, 27, $35 f f, 41,65 f$.

Frazer, J. G., 7-8.

Freedom, 55.

Freud, S., 79, 97, 109ff.

God, 55ff.

Goethe, 3-4.

Group selection, Io.

Haeckel, E., 95-96.

Hall, G. S., 94, 97, 99, 103, 105, II3, II 9 .

Hocking, W. E., 16, 36, 39-40.

Holt, E. B., 7I, 106-07.

Idealism, 19, I18ff.

Immortality, $55 \mathrm{ff}$.

Instincts in feligion, $78 f$.

Indeterminism, 55, 57-58.

James, Wm., 2, 16ff, 28-29, 33ff, $55 f, 70-71,75-76,82,87$, 104, 108.

Kidd, B., 24.

Kipling, 36 .

Leroy-Beaulieu, P., 23-24.

Leuba, J. H., 2, 4, 40, 94.

Lowell, 63-64.

Materialism, 2, I19-20.

McDougall, W., 9, 23-24, 26, $77 f f, 97-98,108,112-13$.

Meinong, A., 43.

Metaphysics, II5ff. 
Moore, G. E., 6, 28.

Moore, J. S., 42, 47-48, 65ff.

Morality and religion, 9, 120 .

Müller, F., 95.

Münsterberg, H., 108.

Mysticism, 34ff, 63.

Natural selection, 8, 14-15.

Nature religions, 14, I00-01.

Nitti, F. S., 23.

Optimism, and religion, 15-16, 18-19.

Browning's, 18-19.

Partridge, G. E., 103.

Perry, R. B., 33-34, 49-50, 89.

Pessimism, I6ff, 69, 83 .

Pfleiderer, O., 9.

Philosophy, religious and moral value of, II fff.

Plato, 79.

Pragmatic fallacy, 19, 27 ff, 42ff, $64-65,67,69,82,92$.

Pragmatism, 29, 69, 84, 86ff. And Darwinism, $69 f$.

Rashdall, H., 7.

Read, C., $5 f f$.

Recapitulation, theory of, $95 f f$. Recapitulatory theory of religious education, $95 f f, 102 f f$, I09.

Redemptive religions, 14, 100.

Religion, and morality, 9, 120. And sex, 38, 40, 79-80. Instincts in, $78 f f$.

Religious belief, biological value of, Iff, 14, 74ff.
Objects of, 55 .

Values of, 8ff, 53ff, 6г ff, 81.

Value of false, 2, 32 .

Religious education, $93 \mathrm{ff}$.

Religious values, classification of, $49 f f$.

Royce, J., 39, 4I.

Russell, B., I5-16, 23, 28, 75, 87.

Santayana, 63.

Schiller, F. C. S., 42, 68ff, 8Iff, 120.

Scientific attitude, 75,87 .

Sex and religion, 38, 40, 79-80.

Sex, sublimation of, rogff.

Siebeck, H., 101.

Soul, 55, 57.

Stages of individual development, 99, 101-02.

Stages of religious evolution, IOoff.

Sublimation of sex, $109 f$.

Survival value of religious belief, 43, 81.

Taboo, 3, 7, 10-11, 102-03, 106.

Theism, 33 .

Thomson, J., I7.

Thorndike, E. L., 72, 97.

Truth, 28, 53-54, 63-64, 73-74, 82 ff, $91-92$. And value, 6, 28-29, 68ff. Test of, 3I, 37 .

Value, meaning of, $43 f f$.

Watson, J. B., 72.

Webb, S., 24-25.

World War, 89. 
, 
THE NEW YORK PUBLIC LIBRARY

REFERENCE DEPARTMENT

This book is under no circumstances to be taken from the Building

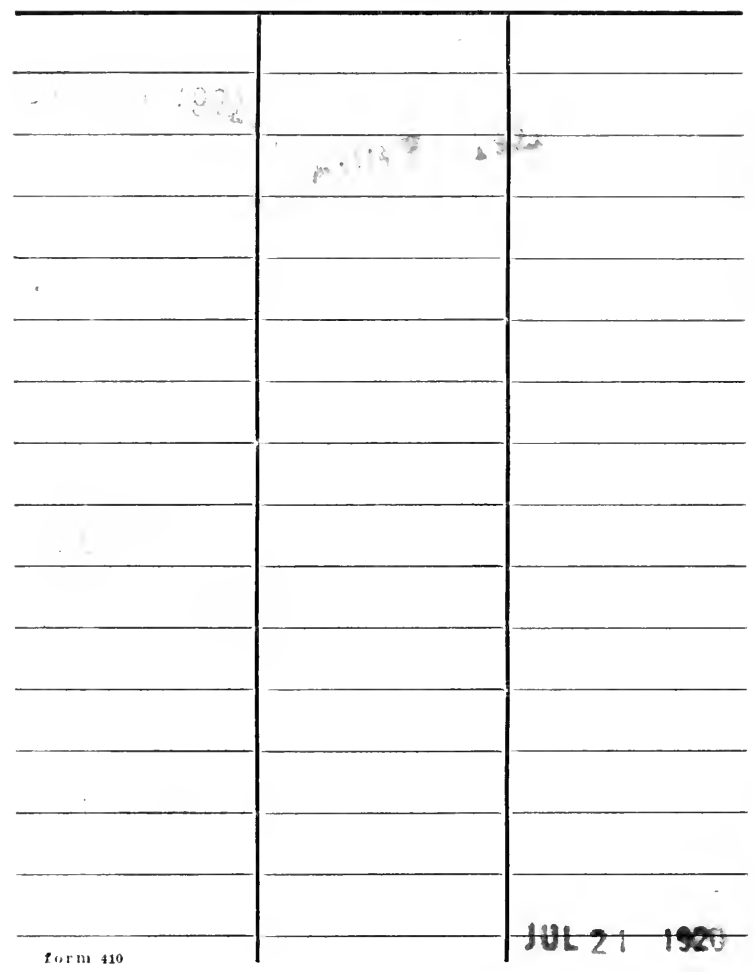




।

$$
\therefore
$$




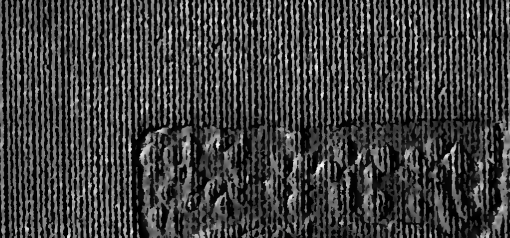

(3) Hom

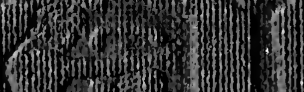

\section{(1)}

